\begin{tabular}{c}
\hline Review of \\
ECONOMICS \\
and \\
INSTITUTIONS
\end{tabular}

\title{
Innovation and Growth: Considerations for Public Policy
}

\author{
Ben Westmore \\ $O E C D$
}

\begin{abstract}
This paper uses panel regression techniques to assess the policy determinants of private sector innovative activity - proxied by R\&D expenditure and the number of new patents - across 19 OECD countries. The relationship between innovation indicators and multifactor productivity (MFP) growth is also examined with a particular focus on the role of public policies in influencing the returns to new knowledge. The results establish an empirical link between R\&D and patenting, as well as between these measures of innovation intensity and MFP growth. Innovation specific policies such as R\&D tax incentives, direct government support and patent rights are found to be successful in encouraging the innovative activities associated with higher productivity growth. However, direct empirical evidence of the positive effects of these policies on productivity is less forthcoming. A pervasive theme from the analysis is the importance of coupling policies aimed at encouraging innovation or technological adoption with well designed framework policies that allow knowledge spillovers to proliferate. In particular, the settings of framework policies relating to product market regulation, openness to trade and debtor protection in bankruptcy provisions are found to be important for the diffusion of new technologies.
\end{abstract}

JEL classification: L20; O30; O40

Keywords: intangible assets, innovation, productivity growth, public policy

This article is based on a previous article that appeared in OECD Economic Studies. The opinions expressed and arguments employed herein do not necessarily reflect the official views of the $O E C D$ or of the governments of its member countries.

Address: Structural Policy Analysis Division, Economics Department. Organisation for Economic Co-operation and Development (OECD), 2, rue André Pascal - 75775 Paris Cedex 16 (Phone: +33 1452415 85, E-mail: Ben.Westmore@oecd.org)

\section{Recommended Citation}

Westmore, B. (2013). Innovation and Growth: Considerations for Public Policy. Review of Economics and Institutions, 4(3), Article 3. doi: 10.5202/rei.v4i3.128. Retrieved from http://www.rei.unipg.it/rei/article/view/128 


\section{Introduction}

Beginning with the work of Solow (1956), the importance of innovation as a driver of long-term economic growth has long been recognised. Such activity may be characterised by positive externalities, as innovation by one entity can produce knowledge spillovers which benefit followon innovators. The fact that these spillovers are often non-rival and non-excludable results in the social rate of return to many innovative activities exceeding the private rate of return (Arrow, 1962). As a consequence, private firms tend to under-invest in innovation, potentially motivating public policy intervention to boost innovative activity to more socially optimal levels.

This paper investigates the influence of public policies on private sector innovation and the returns to new knowledge. The analysis uses countrylevel data to assess: i) the policy determinants of business research and development $(R \& D)$; ii) the policy determinants of the number of new patents; and iii) the link between innovative activity and multifactor productivity (MFP). One benefit of studying innovation at the aggregate instead of the sectoral or firm level is that the spillover effects between firms, industries and countries that are associated with innovation are better identified (Guellec and Van Pottelsberghe, 2003). Spillovers are critical in determining the degree to which new technologies, production processes and organisational methods translate into economy-wide productivity gains, and public policies may play a role in shaping this process. Nevertheless, a possible downside to an aggregate-level study is that the estimated relationships may be more sensitive to changes in sectoral specialisation patterns and less informative about the channels through which policies influence innovation and productivity growth than analysis based on more disaggregated data.

This study is conducted over three separate panels of 19 countries ${ }^{1}$ from the mid-1980s to 2008 and is an update and extension of earlier OECD work by Jaumotte and Pain (2005). Building on the past work, this paper contributes to the existing literature by identifying a number of important considerations for the formulation of government innovation and framework policies, with a particular emphasis on policy interactions. A number of key findings emerge from the analysis:

Both business and non-business R\&D are positively related to patenting activity. In turn, business R\&D and the stock of patents are associated with higher MFP growth.

More generous innovation-specific policies are found to encourage private sector innovative activity, though empirical evidence regarding the direct impact of such policies on MFP growth is less forthcoming. In particu-

1 Countries included are Australia, Austria, Belgium, Canada, Denmark, Finland, France, Germany, Ireland, Italy, Japan, Netherlands, Norway, Portugal, Spain, Sweden, Switzerland, United Kingdom and the United States of America. 
lar:

- R\&D tax incentives are positively associated with recorded private sector R\&D spending. However, this does not hold in countries that frequently reverse policy settings, suggesting that a predictable policy environment may be important for the efficacy of such measures.

- In contrast with some earlier studies, direct government support for private $R \& D$ is found to be positively associated with business $R \& D$ spending. This finding relies on data from the post-2000 period, raising the possibility that the design of such policies has improved through time.

Framework policies that promote competition have a pervasive influence on incentives to innovate and the returns to new ideas. For example:

- Pro-competition reforms to product market regulation are associated with an increase in the number of patents. There is also some, albeit weaker, evidence that such reforms encourage higher business R\&D spending.

- Stronger patent rights are associated with higher patenting activity when regulatory barriers to firm entry are low, highlighting the importance of young firms in maximising the spillovers from new knowledge.

- Domestic patenting activity may benefit from access to foreign R\&D, but only when combined with low barriers to firm entry. Such an environment mitigates the opportunity for incumbent firms with monopoly rights over existing technologies to resist the adoption of innovations from abroad.

- Less stringent product market regulation is associated with higher MFP growth. This may reflect easier implementation and commercialisation of new ideas in more competitive markets.

- Provided that domestic barriers to firm entry are low, countries with greater geographical proximity to technological leader countries exhibit stronger MFP growth.

Other framework policies relating to trade and bankruptcy laws may also be important for the diffusion of innovations from abroad. In particular:

- Countries behind the productivity frontier converge more rapidly as trade openness increases.

- Convergence is faster in countries with bankruptcy regimes that are less punishing to debtors. This may reflect the fact that low exit costs make it less likely that resources are tied up in inefficient firms.

The next section examines the existing evidence of the links between innovation and productivity growth, outlining a framework for thinking about the relationship between the variables of interest and the influence of public policies. Section 3 describes three empirical models that seek to explore the links between a range of potentially relevant policy variables and the key outcome variables relating to business R\&D, the number of new patents per capita and multifactor productivity growth respectively. Section 4 describes the data used for the analysis and Section 5 presents the econometric results. Section 6 summarises the findings and offers some 
concluding thoughts.

\section{Innovation and Public Policies in OECD Coun- tries: Existing Evidence}

A large volume of literature has found that the majority of income differences in developed economies cannot be explained by the stock of labour and tangible capital resources (Caselli, 2005). The residual is ascribed to differences in productivity that depend on countries' ability to accumulate intangible assets, not least through the process of innovation and its diffusion. For each of the 19 OECD countries in the sample, Figure 1 plots the evolution of a measure of MFP that accounts for the capital stock and employment adjusted for human capital (Panel A), along with the business R\&D stock to GDP (Panel B) and the stock of triadic patent families (Panel C). ${ }^{2}$ Before proceeding, it is important to recognise that such measures of MFP are prone to measurement error as they are derived as the residual once the other (imperfectly measured) production factors are taken into account. That said, common patterns in measured productivity have recently been exhibited across the countries in the sample, with average MFP growth generally slowing since 2000 relative to the previous decade. ${ }^{3}$

Empirical studies tend to find a positive link between business R\&D and measures of innovative outputs such as new patents (see Danguy et al., 2009 for a review) and more importantly, productivity growth (see Nadiri, 1993 or Hall et al., 2009 for a review) ${ }^{4}$ Examining trends in these variables indicates that in Belgium, Canada, Ireland and the United States, a slowing in the pace of productivity growth since 2000 has occurred at the same time as weaker growth in the stock of business R\&D (to GDP) and patents. Nevertheless, movements in productivity growth in a number of countries do not seem to accord with trends in R\&D and patents. Certainly, recent declines in productivity in many regions are difficult to reconcile with increases in the

2 A triadic patent family is a series of patents for the one invention filed at the European Patent Office and the Japan Patent Office, and granted at the United States Patent and Trademark Office. These are generally high value patents less affected by patenting propensity than other measures (de Rasenfosse \& van Pottelsberghe, 2008).

3 This is the case in 17 of the 19 countries even if the post-2007 financial crisis period is excluded from the calculation.

${ }^{4}$ Innovation is the result of a range of activities including R\&D, informal learning by doing, non-R\&D knowledge building expenditures as well as the registration and commercialisation of new ideas. While R\&D expenditure and the number of new patents are the most suitable proxies for innovation when making comparisons across time and countries, they do not capture the full range of such activity and can be affected by factors outside the innovation process. For example, a patent does not reflect the quality of new ideas and can be lodged for strategic purposes such as earning licensing revenue, for increasing the chance of attracting capital or as a negotiation tool with competitors and collaborators (Danguy et al., 2009). 
stock of business R\&D and patents over the period.5 Taken together, these trends suggest that while it is important to gain a better understanding of the policy determinants of business $R \& D$ and patenting activity, it is also necessary to investigate the factors that may influence the degree to which such innovative activity is reflected in movements in measured productivity growth.

The innovation process is complex and can vary greatly across industries and technologies. Nonetheless, at the aggregate level, there are some general theoretical links that are useful in interpreting the empirical analysis that follows.

From an initial knowledge state that is drawn upon throughout the innovation process, firms invest in R\&D in the conviction that growth in the stock of such activity improves the probability of innovative success - which can be imperfectly proxied by the number of new patents ${ }^{6}$ The nonrivalrous nature of knowledge means that it is possible for novel ideas generated from $R \& D$ to be used by other innovative entities at no additional cost, enabling increasing returns to $R \& D$ in terms of the number of new patents. Likewise, a subsequent rise in the stock of patented ideas can benefit multiple follow-on innovators, as a condition of being conferred patent rights is that the patent holder publicly discloses technical information regarding the underlying innovation. R\&D may also contribute to increasing the stock of technological advances that are not patented. In the case of non-patent intangibles, firms can use other methods of appropriating returns such as secrecy, barriers to entry and long lead times.

New ideas - patented or not - are absorbed into the knowledge stock and can contribute to higher productivity as they are utilised to produce a higher volume of output for the same volume of inputs.7 The effect on productivity is the focus of the analysis that follows, but it should be acknowledged that, in the short to medium term, the gains from innovation could come in the form of higher firm profits as innovations may lower input costs or allow firms to raise finished good prices without increasing the volume of output. The magnitude of the effect on productivity is likely to be influenced by the quality and execution of new ideas as well as the size of the spillovers that exist. Each stage of the innovation process will be influenced by government policies relating specifically to innovation as well

\footnotetext{
5 This seeming inconsistency may also have to do with the fact that the knowledge-based capital thought to underlie innovation comprises a broader range of assets than just R\&D and patents.

6 The estimated relationship between R\&D and patenting tends to be weaker in studies utilising within-firm or industry level data (Czarnitzki et al., 2008; Hausman et al., 1984) than in a number of cross-country panel studies (de Rassenfosse and van Pottelsberghe, 2009; Falk, 2004b; Jaumotte and Pain, 2005; Jaffe and Sanyal, 2005). This may reflect the presence of spillovers to R\&D that are better captured at higher levels of data aggregation.

7 The amount of R\&D may also influence the ability of firms to absorb new knowledge (i.e. Griffith et al., 2004) and hence the productivity effects.
} 


\section{Figure 1 - Cross Country Differences in MFP, the Business R\&D Stock to GDP and the Patent Stock}

\section{Panel A: Multifactor Productivity}
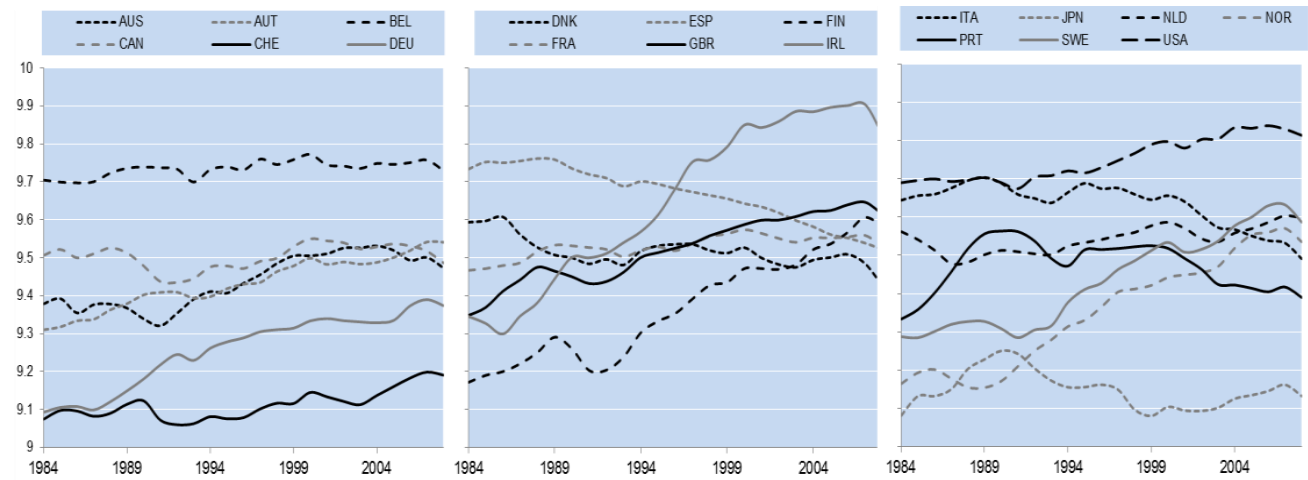

Panel B: Business R\&D stock to GDP (\%)
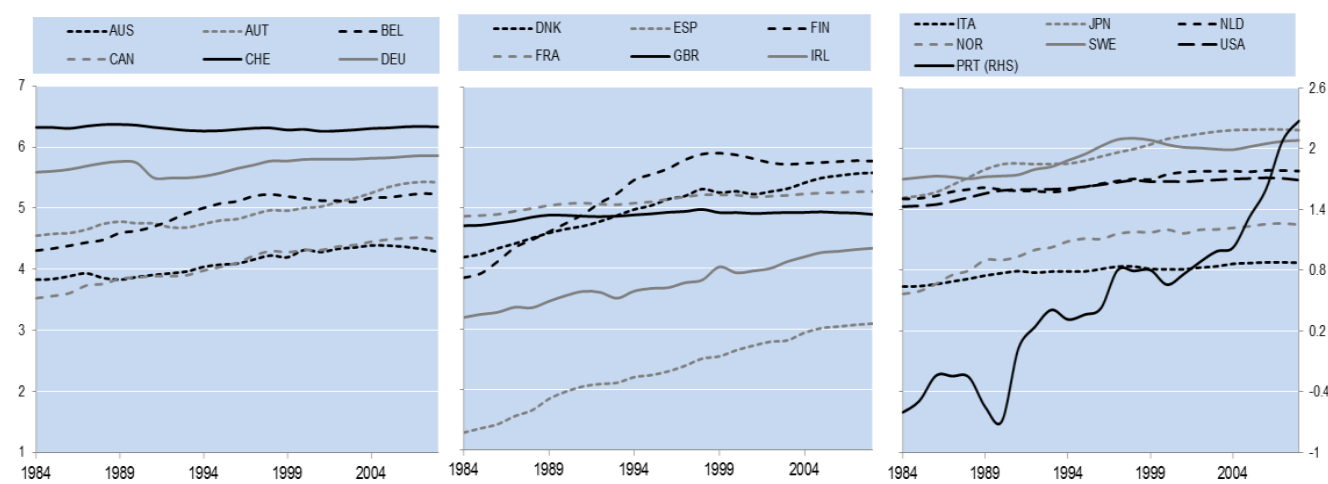

Panel C: Patent stock per capita
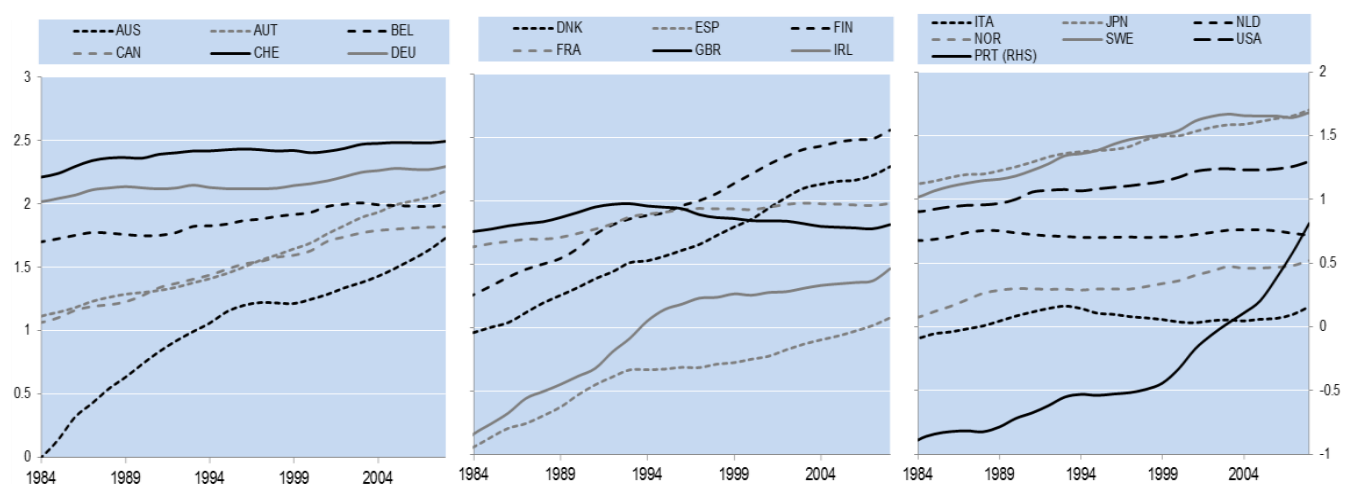

Source: The stock of R\&D and patents per capita (million working age population) are author's calculations based on data from OECD Science and Technology Indicators. MFP data are taken from Johansson and Murtin (2012) and, along with the business R\&D stock to GDP, are calculated from data in constant 2005 PPP USD terms. Panel $\mathrm{C}$ shows signs of a possible data break in Germany around the time of the country's reunification. However, unreported regressions controlling for this break confirm that the estimation results reported in Section 5 are robust to this feature of the data. 


\section{Figure 2 - R\&D Tax Incentives}

The B-index at 1985 and 2008

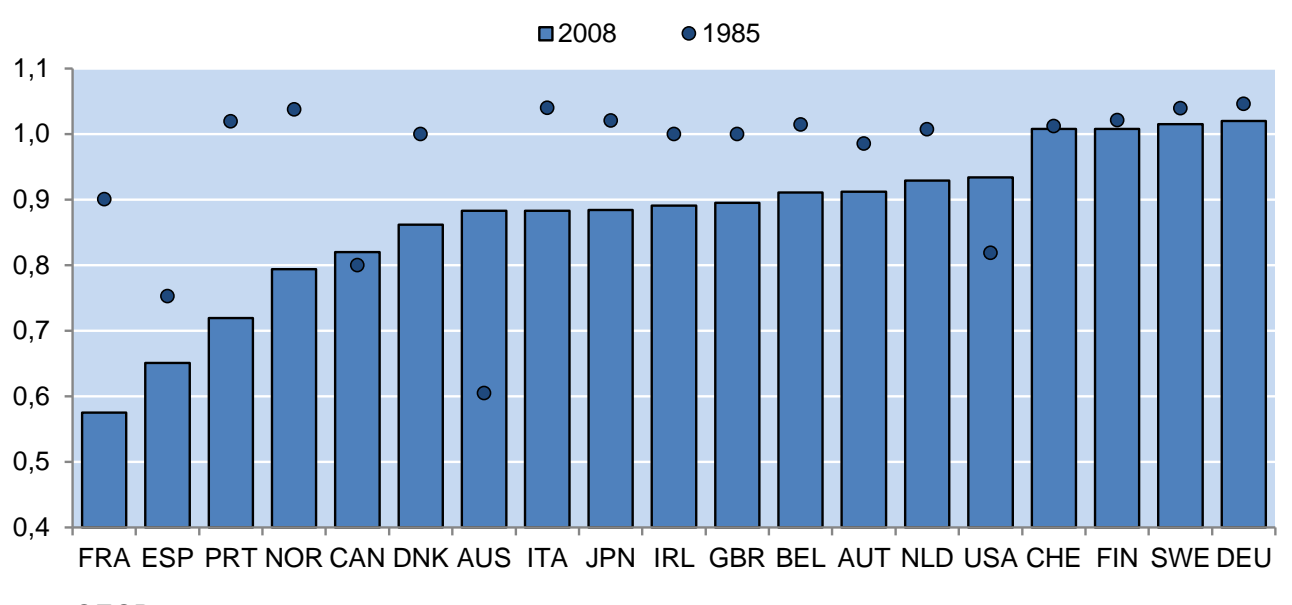

Source: OECD

as economy-wide framework policies, which are now discussed in turn.

\section{Innovation Policies}

Innovation-specific policies strengthen business incentives to innovate, counteracting the private underinvestment in such activity. A number of such policies are targeted to particular types of firms or industries, and hence, may be best analysed using event studies or data at a highly disaggregated level. The analysis in this paper focuses on a few larger scale innovation policies for which relatively reliable cross-country data exist and that are suspected to directly influence the dependent variables of interest.

$R \& D$ tax incentives can take various forms but are market-based instruments that leave firms to decide which $R \& D$ activities to fund. Either expenditure-based schemes (i.e. R\&D tax credits, tax allowances and payroll withholding tax credits for R\&D wages), or income-based schemes (i.e. taxing income derived from knowledge-based capital at a preferential rate), can be implemented. The overall generosity of R\&D tax incentives can be summarised by the B-index (Warda, 2001), which represents the required rate of pre-tax return to justify $\$ 1$ of $R \& D$ outlay taking account of both $\mathrm{R} \& \mathrm{D}$ tax incentives and the corporate income tax rate. Consequently, an increase in R\&D tax incentives is reflected by a decline in the B-index.

A comparison of the level of the B-index for the sampled countries in 1985 and 2008 highlights that R\&D tax incentives in most countries have become more generous in recent years, but important cross-country differences remain (Figure 2).

The majority of existing cross-country studies find that tax incentives are effective in explaining the evolution of business R\&D with a long-run elasticity around unity: on average, one dollar of tax incentive eventually in- 
duces one dollar of recorded private R\&D spending (Hall and Van Reenen, 2000). This may vary with the design of the incentive, with incremental tax credits (i.e. R\&D expenditures are only eligible if they exceed some baseline amount) sometimes found to be more effective in inducing business R\&D spending than general - volume-based - tax credits (i.e. all R\&D expenditures are eligible; Lokshin \& Mohnen, 2009). Regardless, the implications for economic welfare are unclear since the introduction of an R\&D tax incentive raises administrative and compliance costs as well as the need for financing through distortionary taxation.

Direct government funding of private $R \& D$ is an additional innovation policy that can vary significantly in the way it is administered (for an overview, see Blanco Armas et al., 2006). Grants, loans, loan guarantees or procurement contracts are all ways that governments can directly support business R\&D, though each may have quite different objectives. For instance, in many countries, government loans support private $R \& D$ activities that are focused on the needs of civilians, while the type of private R\&D procured by government is often defence-related. Taking all direct support measures together indicates that while there is significant cross-country variation in the ratio of government financed business R\&D to GDP, direct funding has generally become less supportive of $R \& D$ over the past few decades (Figure 3 ). One reason for this trend in some countries is a gradual decline in the intensity of military spending and, hence, government procurement of private defence-related R\&D. However, in almost all of these regions, the pace of decline in government support for private R\&D has markedly exceeded that in military spending.

In general, there appears to have been a decrease in the reliance of governments in the sampled countries on direct support policies in favour of $R \& D$ tax incentives. This may reflect a growing acknowledgment that although, in principle, direct funding schemes allow governments to select R\&D activities with the highest marginal social returns, in practice, identifying such projects can be complicated by information asymmetries and decisions may be influenced by rent-seeking entities.

The tendency for governments to move away from direct support has been reinforced by a body of empirical research that remains inconclusive as to whether such schemes encourage additional private R\&D (David et al., 2000). Instead, it may be that firms substitute public R\&D funds for their own or that subsidies feed into higher wages rather than greater innovation intensity (Goolsbee, 1998; Jaumotte and Pain, 2005).

Whether government assistance is provided through tax incentives or direct funding, there is some evidence that the effect of such R\&D policies can be undermined if they are particularly "unstable" - proxied by the standard deviation of policy variables (Guellec and Van Pottelsberghe, 2003). Cost certainty is important for many R\&D projects given that they often have a multi-year horizon and the investment decision is difficult to reverse once 


\section{Figure 3 - Government Financed Business R\&D}

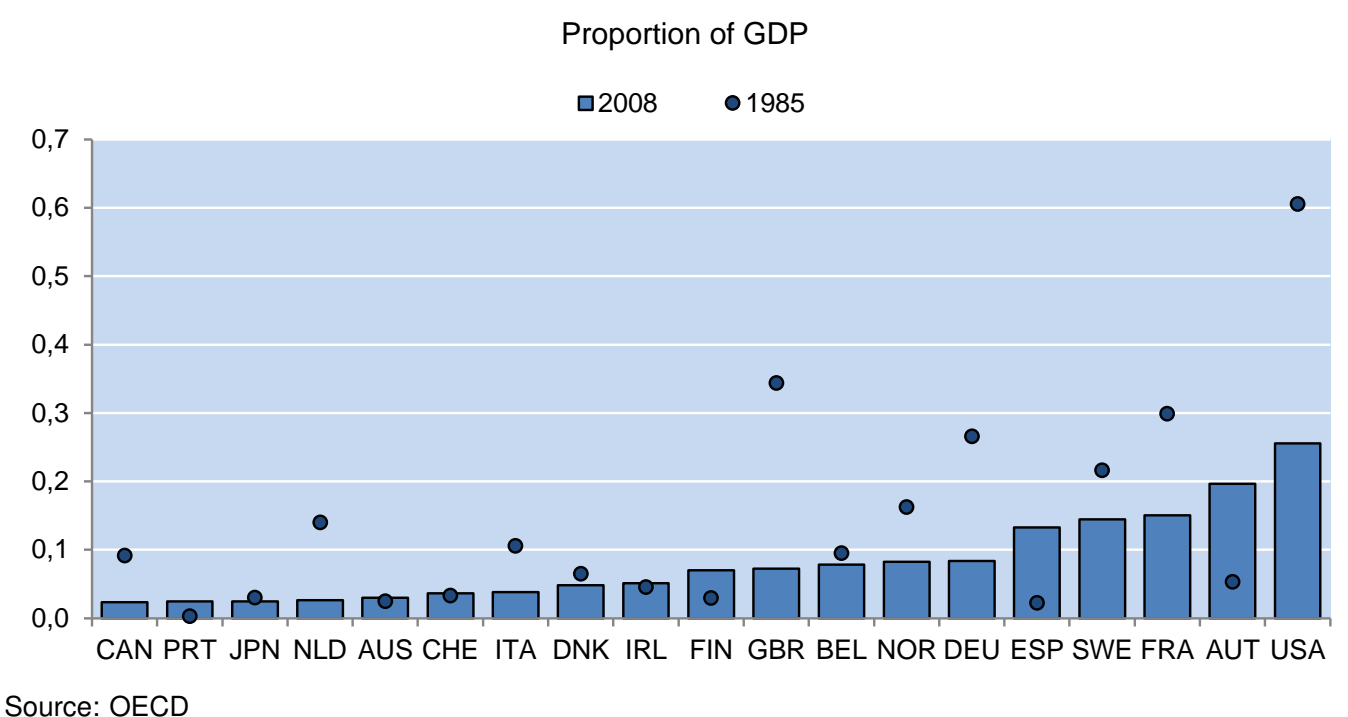

the project is commenced (Pindyck, 1992). It may be, however, that unstable but predictable policy movements still allow private firms to confidently plan and implement R\&D projects. As such, a better proxy for policy instability may be a measure of the frequency with which policy has reversed course, rather than simply an indicator of the dispersion of policy from its mean over a given period.

Measuring the unpredictability of R\&D tax policy as the number of instances in which the B-index immediately reversed course over the 19812008 period highlights significant dispersion across the countries in the sample (Figure 4) ${ }^{8}$ Moreover, a simple regression between this variable and the within country standard deviation of the B-index suggests that the two measures are not statistically related to one another.

Governments also undertake R\&D activity themselves, which may support commercial innovation. Recent country level empirical studies find that non-defence related public research tends to have a neutral effect on business R\&D; not encouraging nor substituting for private research (Guellec and Van Pottelsberghe, 2003; Montmartin, 2013). While history provides numerous instances of government research being at the root of revolutionary commercial technologies, the lags can be long and unpredictable and thus difficult to identify empirically (Sheehan and Wyckoff, 2003). A common example is the internet revolution of the past few decades, which evolved from government investments made as far back as the 1960s.

Patent rights are a method for the government to temporarily grant an inventor the ability to restrict the use of their invention in exchange for the

\footnotetext{
8 The tax policy reversals variable is calculated by tallying the number of times that a country implements more generous R\&D tax policy immediately after implementing less generous policy or vice versa over the sample period.
} 


\section{Figure 4 - Cumulative Reversals in R\&D Tax Policy}

1982-2008

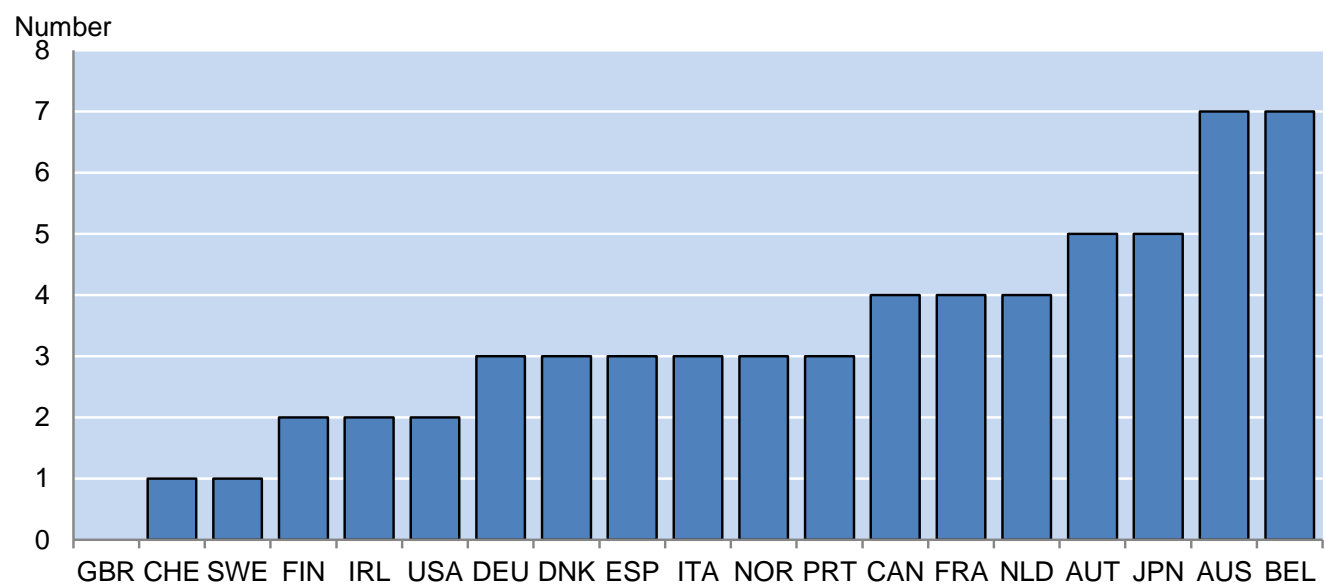

Source: Authors calculations based on data from the OECD Science, Technology and Industry Outlook

\section{Figure 5 - Patent Rights}

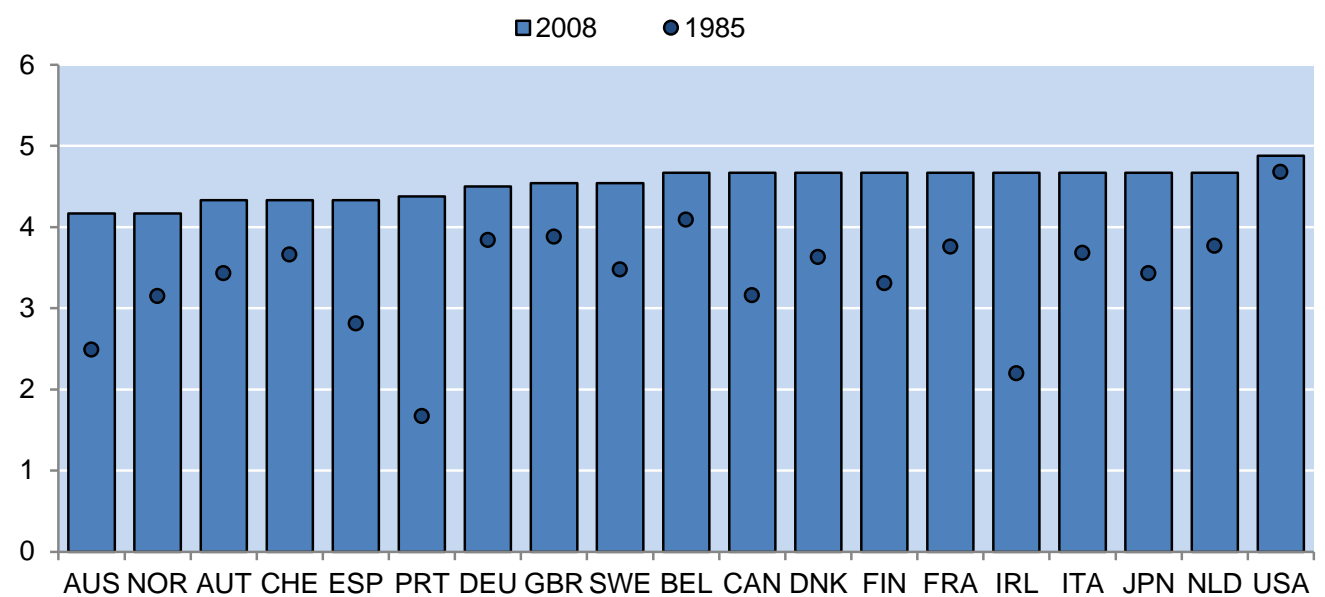

Source: Park (2008)

technical details being made public. In strengthening such rights, a delicate balance exists between granting firms some market power to encourage innovation on the one hand, and ensuring that the competitive forces that prevent abuses and motivate subsequent innovation and diffusion of ideas are not stifled on the other. For many years there was a general tendency for countries to increase the amount of protection given to patent holders (Figure 5). However, in the past decade or so, most OECD countries have maintained a relatively stable intellectual property rights (IPR) regime. One consequence of this for empirical analysis is that it may be difficult to identify a causal effect of patent rights (Falk, 2004b). Nonetheless, there is some recent evidence of the positive effect of stricter patent rights on productivity in patent intensive manufacturing industries ( $\mathrm{Hu}$ and Png, 2013). 


\section{Framework Policies}

Framework policies that promote domestic and international competition (Conway et al., 2006, Coe and Helpman, 1995) and adaptable labour markets (Bassanini et al., 2009) have been identified as important for fostering productivity growth. A channel through which this may occur is via the effect on the innovation process. In particular, framework policies may influence the ability and incentive of firms to undertake innovative activity, attract resources to commercialise new ideas, scale back outdated activities and to take advantage of knowledge spillovers from earlier innovations.

The relationship between competition and private sector innovation is likely to vary depending on the particular attributes of the firm or market. While some models advocate competition on the basis that firms with high market power may be disinclined to pursue innovation that may displace existing rents (Arrow, 1962; Reinganum, 1983), early Schumpeterian growth models (Aghion and Howitt, 1992) highlight that the incentives for innovation (in terms of prospective post-innovation rents) may increase at lower levels of competition. Indeed, recent empirical work indicates heterogeneity across industries. Using panel data from the United Kingdom, Aghion et al., (2005) find that innovation will benefit from a reduction in product market regulation (PMR) in initially high-PMR industries, but may be harmed in those industries that are already highly competitive. Thus, the aggregate impact of PMR on innovation is theoretically ambiguous and becomes an empirical issue.

The stringency of labour market policies may also have consequences for private innovation. By allowing resources to flow to their most productive uses, easier employment protection legislation (EPL) is thought to benefit entrepreneurial firms undertaking radical innovations (Saint-Paul, 1997, 2002; Bartelsman et al., 2010) that require relatively large employment adjustments (Aghion and Howitt, 1997). This is supported by recent empirical evidence that higher EPL reduces $R \& D$ expenditure in innovative industries and that this effect is disproportionally large in sectors that are particularly turbulent (Andrews and Criscuolo, 2013).

Lowering EPL may not be unequivocally good for all firms. Acharya et al., (2010) find a positive relationship between stricter labour laws governing dismissal of employees and patenting, arguing that employees may be incentivized to undertake innovative activities that are value maximizing in the long run if they do not fear losing their job. Similarly, greater employment protection may encourage firms to invest in firm-specific human capital that benefits productivity (Autor, 2003; Wasmer, 2006). Griffith and Macartney (2010) find that multinational firms do more patenting of incremental innovations in relatively high EPL countries and more patenting of radical innovations in low EPL countries. Such heterogeneous effects indicate that it may be difficult to identify the impact of a change in EPL on R\&D 
expenditure or patenting in a cross-country study based on aggregate data.

Policies that promote international trade may also have a positive influence on domestic innovation as firms are more exposed to the foreign stock of R\&D and new technologies, production processes and organisational methods (Jaumotte and Pain, 2005; Falk, 2004a). Nevertheless, it is possible that access to foreign R\&D may provide a disincentive for domestic R\&D expenditure and that the two sources of R\&D are partly substitutable.

Financial sector policies that influence the availability of credit or equityfinancing to businesses may affect the existence and success of innovative firms. R\&D projects often require substantial investments that need to be funded from retained earnings or external sources. However, many innovative firms are small and young with limited internal income or assets and have difficulty obtaining external private finance given that the outputs to innovation are relatively uncertain. Some existing studies find a positive impact of access to particular types of finance and business R\&D intensity (Maskus et al., 2012), though excessive financial liberalization may have negative consequences for knowledge accumulation by increasing market volatility or reallocation of workers away from innovative sectors (Ang, 2011).

Government policies relating to bankruptcy procedures are likely to be important for firms engaged in radical innovation activities that expand the technological frontier. Such innovation is synonymous with entrepreneurship and experimentation strategies that imply frequent and repeated failure (Bartelsman et al., 2008). Countries that impose high exit costs for failed firms - through more punishing bankruptcy regimes - may deter experimentation, lowering the capacity for innovation. However, some investor protection is necessary, especially given that the availability of finance may be positively related to the degree of creditor recourse.

It should now be apparent that there are a range of policy tools that may influence the volume of private $R \& D$, patenting and other types of innovation activity. However, a number of these policy instruments are likely to interact, potentially complementing one another or leading to policy conflicts. One such interaction may arise when the success of a policy in meeting its objective is influenced by the settings of other policy instruments. Parente and Prescott (2000) highlight the case of trade openness which enables the adoption of new innovations from abroad, though such activity may be limited if high barriers to firm entry in the domestic market lead to incumbents that own existing technology resisting the adoption process. Another form of interaction may occur when a policy adjustment creates distortions unless other policy settings are correctly calibrated. For example, an increase in patent rights designed to provide firms an incentive to engage in innovative activities may result in innovators creating monopolistic positions. In this case, it may be important to ensure that IPR policy settings are complemented by pro-competition product market regulations 
(OECD, 2006; Uppenberg, 2009). Such policy interactions are an issue that has received relatively limited attention in the existing empirical literature but which this paper investigates further.

\section{Empirical Model}

\section{RED Model}

The approach to modelling R\&D corresponds to that of Jaumotte and Pain (2005) in the spirit of earlier work by Bloom et al., (2002). This assumes that the stock of real $R \& D$ is one input into a production process approximated by a CES production function. Taking the first order condition that $R \& D$ investment is undertaken up to the point where marginal revenue equals marginal cost, the following long-run relationship is derived:

$$
\ln R D S_{i t}=\alpha_{i}+\beta_{i} \ln Y_{i t}+\tau \ln \text { user cost } \cot _{i t}+\sum_{j=1}^{n} \varphi_{j i} Z_{j i t}+u_{i t}
$$

For country $i$ at time $t$ the R\&D stock is determined by real output $(Y)$, the real user cost of $R \& D$ and a vector of additional influences $(Z)$. Long-run constant returns to scale would imply $\beta_{1}=1$.

An empirical specification is then derived explaining privately-funded business R\&D, reflecting both short-run dynamics and divergences from an underlying long-run relationship. This acknowledges that it may take time for $R \& D$ to react to changes in its determinants as businesses develop $R \& D$ plans and then obtain the necessary capital and labour resources. The dynamic non-linear error correction relationship is represented by the equation:

$$
\begin{aligned}
\Delta \ln R D S_{i t}= & \alpha_{1 i} \Delta \ln R D S_{i t-1}+\sum_{j=1}^{m} \rho_{j i} \bar{Z}_{j i t}+ \\
& +\theta_{i}\left[\ln \left(\frac{R D S_{i t-1}}{Y_{i t-1}}\right)-\delta \ln \text { user cost } \text { tit-1 }-\sum_{k=m+1}^{n-m} \gamma_{k i} \tilde{Z}_{k i t}\right]+\alpha_{i}+\alpha_{t}+\mu_{i t}
\end{aligned}
$$

The dependent variable is the stock of business $R \& D$ in constant price US dollar purchasing power parity (PPP) terms and excludes expenditures financed by government. The vector $Z$ includes $m$ variables that may affect the short-run evolution of $\mathrm{R} \& \mathrm{D}$ and $n$ variables that explain long-run crosscountry differences in $R \& D$. In both the $R \& D$ and patent regressions, it is anticipated that framework policies will only have a long-run impact as they tend to change very slowly through time. $Y$ is real GDP in constant US dollar PPP terms. Long-run constant returns to scale are imposed, so that while 
the dependent variable is the growth of the R\&D stock the long-run parameters ultimately determine $R \& D$ intensity. This is reflected in the specification of the error correction term. Factors that vary across countries but not across time are captured through country fixed effects, $\left(\alpha_{i}\right)$ while time fixed effects $\left(\alpha_{t}\right)$ are included to absorb common global shocks. The lag length is chosen by running country-specific regressions of a base specification and consulting the Akaike and Schwarz' Bayesian information criterion. 9 The equation is specified as a one-stage error correction procedure instead of an Engle-Granger two-step approach due to the presence of theoretically relevant short-run, often contemporaneous, variables. This specification also allows the flexibility to include a variety of factors believed to share a longrun relationship with the R\&D stock, without imposing strong restrictions on the data generating process (De Boef et al., 1999). ${ }^{10}$

While either the flow or the stock of R\&D can be modelled as the dependent variable, the primary focus of the analysis is the R\&D stock. This owes to the fact that changes in the R\&D stock are most relevant for augmenting the pool of existing knowledge and hence affecting productivity growth.

The construction of the real user cost of $R \& D$ follows Jaumotte and Pain (2005) using an approach similar to that pioneered by Hall and Jorgenson (1967):

$$
\text { user } \text { cost }_{i t}=(B \text {-index }) \times\left(r_{i t}+\delta\right)
$$

where $r$ is the long-term real interest rate and $\delta$ the depreciation rate on $R \& D$ capital, assumed to be $15 \%$ per annum in all countries and time periods (Guellec and van Pottelsberghe, 2004; Hall and Mairesse, 1995).11

\section{Patenting Model}

The model describing the evolution of the number of patents is broadly similar to that for movements in R\&D detailed above. In contrast with the R\&D model, but in keeping with the depiction of the innovation process in Section 2, the dependent variable is based on a flow rather than a stock measure, annual growth in the number of triadic patent families per capita:

$$
\begin{aligned}
\Delta \ln \frac{\text { Pat }_{i t}}{\text { Pop }_{i t}}= & \alpha_{1} \Delta \ln \frac{P a t_{i t-1}}{P_{i t-1}}+\sum_{j=1}^{m} \varnothing_{j i} \bar{Z}_{j i t}+\alpha_{2}\left[\ln \left(\frac{P a t_{i t-1}}{\text { Pop }_{i t-1}}\right)-\alpha_{3} \ln \left(\frac{R D S_{i t-1}}{Y_{i t-1}}\right)\right. \\
& \left.-\alpha_{4} \ln \left(1+\frac{R D S_{i t-1}^{G}}{R D S_{i t-1}}\right)-\sum_{k=m+1}^{n-m} \partial_{k i} \tilde{Z}_{k i t}\right]+\alpha_{i}+\alpha_{t}+\mu_{i t}
\end{aligned}
$$

\footnotetext{
${ }_{9}$ This process is also followed for choosing the lag lengths in the patent and MFP models.

${ }^{10}$ The framework adopted guarantees consistency of estimates, at least in the long run, irrespective of whether variables are stationary or contain unit roots (Pesaran and Shin, 1999).

${ }^{11}$ See Appendix 1 for a more detailed decomposition of the user cost term. Some recent work has suggested that $\mathrm{R} \& \mathrm{D}$ depreciation rates are higher than $15 \%$ (see $\mathrm{Li}, 2012$ ). However, a sensitivity analysis indicates that the conclusions from the estimation results presented later are not highly sensitive to the chosen depreciation rate.
} 
The stock of business sector R\&D and the stock of non-business sector $\mathrm{R} \& \mathrm{D}\left(R D S^{G}\right)$ are included as regressors, reflecting that innovation output is likely to be a function of the knowledge that has built up in an economy over time. The forms in which these terms enter the equation are taken from Jaumotte and Pain (2005), with their separate inclusion designed to highlight any differential effects of the source of R\&D on patenting activity. Pop is millions of working age population (15-64) and the $Z$ terms represent other short-run $(\bar{Z})$ or long-run $(\tilde{Z})$ influences on patenting including government policies. Indeed, it is possible that policies that influence R\&D may have an additional affect on the success of such activity. Country and time fixed effects are also included.

\section{MFP Model}

In the spirit of past models of productivity growth (Nicoletti and Scarpetta, 2003; Griffith et al., 2004; Conway et al., 2006), the MFP equation is specified to allow for the role of technology transfer as a source of productivity growth for countries behind the technological frontier:

$$
\Delta \ln M F P_{i t}=\delta \Delta \ln M F P_{L t}-\rho \ln \left(\frac{M F P_{i t-1}}{M F P_{L t-1}}\right)+X_{i t}^{\prime} \beta+h_{i t}+\alpha_{i}+\tilde{\alpha}_{t}+\epsilon_{j t}
$$

The first term in equation 5 represents MFP growth of the frontier country, while the second term is the productivity gap (in terms of productivity level) and reflects the expectation that productivity growth is higher the further a country is from the frontier. The vector $X$ represents the stock of $R \& D$ or the number of patents as well as other sources of knowledge diffusion that may affect aggregate MFP. The influence of framework policies can be assessed through interacting policy variables with these indicators as well as the frontier gap term (though such interactions are not explicitly illustrated in equation 5). Because the labour input for the calculation of MFP is the number of employed (see Data Annex for more details), a control variable for labour utilisation is included $(h)$ which represents the number of hours worked per employee. Country fixed effects are included and following Bouis et al. (2011), five-year period dummies $\left(\tilde{\alpha}_{t}\right)$ are used to control for common variations in trend productivity growth. Equation 5 can be seen as an error correction model derived from a first-order autoregressive distributed lag process in which the MFP level in each country is cointegrated with that of the leader (Nicoletti and Scarpetta, 2003). The model implies heterogeneity in equilibrium MFP levels, with the productivity gap for each non-frontier country converging to a constant value. As a result, changes in the factors captured by vector $X$ impact the steady state levels of MFP across countries, but do not result in permanent changes in MFP growth rates.

The models represented by equations 2,4 and 5 are estimated across the 19 countries over the 1983-2008 period for the R\&D equation and 1986-2008 
for the patent and MFP equations. ${ }^{12}$ This is the same sample of countries used by Jaumotte and Pain (2005), with seven additional years of data.

Assumptions of independent and identically distributed standard errors within countries are often violated, leading to the clustering of standard errors at the country level. Such a technique allows for a general form of heteroskedasticity as well as intra-cluster correlation (Primo et al., 2007). The fixed effects estimator is used which pools data across the individual countries and in doing so assumes that the long and short-run determinants of $\mathrm{R} \& \mathrm{D}$ are homogeneous across regions. ${ }^{13}$

\section{Data}

Descriptive statistics are found in the Data Annex along with details of the construction of the R\&D stock and MFP level variables used in the analysis. As mentioned, the MFP measure accounts for the contribution of the stock of physical capital and a labour input that is adjusted for changes in human capital. The main constraints to broadening the scope of the analysis (along the country or time dimension) are insufficient data for either R\&D expenditure or the B-index.

The OECD Main Science and Technology Indicators Database is the source of constant price R\&D expenditure, employment and patent data. R\&D expenditure series are available for most countries from 1981 and are deflated using the implicit GDP deflator from the OECD National Accounts Database. For patents, the number of triadic patent families by inventor's country of residence is used. As is generally the case, linear interpolation is performed in instances of missing observations.

The foreign R\&D stock variable is calculated for each country as the trade-weighted $R \& D$ of all other countries in the sample, employing the weighting scheme outlined by Lichtenberg and Van Pottelsberghe (1998). The weights are calculated from bilateral trade flow data from the IMF $D i-$

\footnotetext{
12 Patent data prior to 1986 from the European Patent Office are thought to be unreliable (for details, see Jaumotte and Pain, 2005). The use of starting values in the calculation of the R\&D stock (for details of the construction see Data Annex) allow the R\&D regressions to be run over the 1983-2008 period whether the dependent variable is the change in the stock or flow of R\&D.

${ }^{13}$ The assumption of slope homogeneity can lead to the fixed effects estimator producing inconsistent and potentially misleading results. Alternatively, the mean-group (MG) estimator (Pesaran and Smith, 1995) allows the intercepts, slope coefficients and error variances to differ across countries or the pooled mean-group (PMG) estimator (Pesaran, Shin and Smith (1997)) allows heterogeneous short-run coefficients, intercepts and error variances but constrains the long-run coefficients to be equal. However, conducting Hausman tests on the coefficients of the base R\&D and patent equations estimated with each of the dynamic fixed effects, MG and PMG estimators indicates that pooling across countries yields efficient and consistent estimates and hence, that fixed effects estimation is appropriate. Results are available from the author upon request.
} 
rection of Trade Statistics. ${ }^{14}$

Government financed business R\&D is derived from the OECD Science, Technology and RED Statistics Database. The measure of R\&D tax generosity, the B-index, is available for large firms from 1981 with the historical series updated with data from the 2009 OECD Science Technology and Industry Outlook. In years where data are not available, the series is held constant at the last observed value. In calculating the user cost of R\&D capital, the long-term interest rate is measured from secondary market yields of 10 year government bonds and is taken from the OECD Key Economic Indicators Database.

The measure of patent rights is the cross-country index updated by Park (2008) which increases at higher levels of patent protection. The index takes into account five aspects of patent laws: extent of coverage, enforcement mechanisms, duration of protection, provisions for loss of protection and membership in international patent agreements. The raw data are available at five-year intervals between 1980 and 2005 and, for the purposes of the empirical analysis, the value is assumed to remain at the 2005 level from 2006 to 2008.

The indicator of PMR is the OECD measure of regulation in energy, transport and communications. This index summarises the regulatory provisions in the telecommunications, electricity, gas, post, rail, air passenger transport, and road freight sectors and has a longer time series than other such indicators. While the measure does not cover all industries, it captures those in which anti-competitive regulation tends to be most concentrated in the sample countries. The 'high barriers dummy' appearing in the patent and MFP regressions captures regulatory or administrative barriers to firm entry (Wölfl et al., 2009).15 The measure of EPL relates to both regular and temporary contracts from the OECD Employment and Labour Market Statistics (for further details, see Nicoletti et al., 2000).

The index of banking regulation used in the $R \& D$ regressions does not have a time dimension and is taken from de Serres et al., (2006) and compiled from the World Bank's Bank, Regulation and Supervision Database that draws on responses to a survey conducted in 2003. The measure increases with the level of regulation in two broad areas: barriers to competition (relating to regulations for domestic entry, foreign entry, banking activity and government ownership) and stability (relating to accounting standards, auditing requirements, capital adequacy, liquidity and diversification, provisioning,

\footnotetext{
${ }^{14}$ For example, in calculating the foreign R\&D stock of country $i$ in time $t$, the R\&D stock of trading partner $j$ is weighted according to the trade inflows from country $j$ to country $i$ in period $t$.

${ }^{15}$ The dummy variable is constructed from the barriers to entrepreneurship (overall) subindex of the OECD indicator of economy-wide PMR. This measure reflects obstacles to easy access to information on existing regulation, general or sector-specific administrative burdens for business start-ups and other general or sector-specific regulations that hinder firm entry.
} 
internal management, ownership, discipline and enforcement, deposit insurance and supervisory structure). The bankruptcy cost variable is a timeinvariant indicator of the cost to close a business in 2004 sourced from the World Bank Doing Business project.

Macroeconomic indicators include GDP growth, calculated from a measure of GDP in constant price US dollar PPP terms sourced from the OECD National Accounts Database, and inflation, which is measured by the Consumer Price Index from the OECD Main Economic Indicators Database. In the MFP regressions, average annual hours per worker is taken from the OECD Employment and Labour Market Statistics.16

\section{Estimation Results}

\section{Private Research and Development}

Table 1 presents the results from the estimation of equation 2. As discussed in section 3.1, the analysis is focused on the determinants of growth in the R\&D stock, though the results of a base specification with the R\&D flow as dependent variable is also presented (Column 8). The regressions suggest that government innovation policies as well as some framework conditions are important in explaining the stock of private sector R\&D.

\subsubsection{Innovation Policies}

Consistent with past studies, the long-run effect ${ }^{17}$ of the user cost of R\&D on the stock of private $R \& D$ is estimated to be around unity $\left.\right|^{18}$ There is also evidence of a short-run influence of changes in the B-index, though this effect is estimated to be small relative to the long-run impact of the user cost. The coefficient on the user cost term in Column 7 implies that a decrease in the B-index by 0.05 units (holding long-term real interest rates and the depreciation rate constant) is associated with an increase in the long-run stock of business R\&D by just under $6 \%$. Such an increase in the generosity of R\&D tax policy (decrease in the B-index) is equivalent to a shift in policy settings from those in the United States to the more generous ones of Japan in 2008 (for partial effects of the policy variables, see Table 3).

The coefficient on an interaction term between the long-run user cost and a dummy for countries with a very high number of instances in which R\&D

\footnotetext{
${ }^{16}$ This data is only available for Austria from 1995, constraining the number observations in the MFP regressions to 428 (rather than 437).

${ }^{17}$ While the short-run effects can be obtained from the coefficients of the fixed effects estimator, the long-run effects depend on the speed of adjustment term and require additional computation. The method outlined by Bardsen (1989; see Appendix 2 for details) is used for calculating the long-run coefficients and the associated error variances.

${ }^{18}$ Across the specifications presented in Table 1 Wald tests cannot reject that the long-run parameter equals one.
} 
Table 1 - The Determinants of Business R\&D

\begin{tabular}{|c|c|c|c|c|c|c|c|c|}
\hline \multirow{2}{*}{$1982-2008$} & \multicolumn{7}{|c|}{ Dependent Variable $=\Delta \ln (R \& D$ Stock $)$} & \multirow{2}{*}{$\begin{array}{c}\text { Dependent } \\
\text { Variable }= \\
\Delta \ln (\text { R\&D Flow } \\
(8) \\
\end{array}$} \\
\hline & (1) & (2) & (3) & (4) & (5) & (6) & (7) & \\
\hline \multicolumn{9}{|l|}{ SHORT-RUN DYNAMICS } \\
\hline$\Delta \ln (R \& D$ Stock) $t-1$ & $\begin{array}{c}0.84 * * * \\
(28.28)\end{array}$ & $\begin{array}{c}0.85 * * * \\
(26.01)\end{array}$ & $\begin{array}{c}0.87^{* * *} \\
(22.95)\end{array}$ & $\begin{array}{c}0.84 * * * \\
(29.54)\end{array}$ & $\begin{array}{c}0.85 * * * \\
(26.94)\end{array}$ & $\begin{array}{c}0.84 * * * \\
(33.22)\end{array}$ & $\begin{array}{c}0.84 * * * \\
(29.06)\end{array}$ & \\
\hline$\Delta \ln (\text { R\&D Flow })_{t-1}$ & & & & & & & & $\begin{array}{c}0.28^{* * *} \\
(5.24)\end{array}$ \\
\hline $\mathrm{ECM}_{\mathrm{t}-1}$ & $\begin{array}{c}-0.013 * * * \\
(2.84)\end{array}$ & $\begin{array}{c}-0.012^{* * *} \\
(2.60)\end{array}$ & $\begin{array}{c}-0.012^{* * *} \\
(3.64)\end{array}$ & $\begin{array}{c}-0.013^{* * *} \\
(3.09)\end{array}$ & $\begin{array}{c}-0.014^{* * *} \\
(3.31)\end{array}$ & $\begin{array}{c}-0.027^{* * *} \\
(5.54)\end{array}$ & $\begin{array}{c}-0.013^{* * *} \\
(3.18)\end{array}$ & $\begin{array}{c}-0.06 * * * \\
(2.88)\end{array}$ \\
\hline $\mathrm{ECM}_{\mathrm{t}-1}{ }^{*}$ (banking reg) & & & & & & $\begin{array}{c}0.006^{* *} \\
(2.55)\end{array}$ & & \\
\hline$\Delta \ln (B \text {-index })_{t}$ & $\begin{array}{c}-0.03 * * \\
(1.96)\end{array}$ & $\begin{array}{l}-0.03^{*} \\
(1.84)\end{array}$ & & $\begin{array}{l}-0.04 * \\
(1.95)\end{array}$ & & $\begin{array}{c}-0.04 * * \\
(2.09)\end{array}$ & $\begin{array}{l}-0.03^{*} \\
(1.87)\end{array}$ & $\begin{array}{l}-0.08 \\
(1.25)\end{array}$ \\
\hline Inflation $\mathrm{t}-1$ & $\begin{array}{c}-0.13^{* * *} \\
(3.47)\end{array}$ & $\begin{array}{c}-0.12 * * * \\
(2.78)\end{array}$ & & $\begin{array}{c}-0.14 * * * \\
(3.30)\end{array}$ & $\begin{array}{c}-0.13 * * * \\
(3.10)\end{array}$ & $\begin{array}{c}-0.13^{* * *} \\
(3.80)\end{array}$ & $\begin{array}{c}-0.14^{* * *} \\
(3.20)\end{array}$ & $\begin{array}{c}-0.50 * * * \\
(3.61)\end{array}$ \\
\hline GDP growth $\mathrm{t}$ & $\begin{array}{c}0.10^{* *} \\
(2.36)\end{array}$ & $\begin{array}{c}0.098^{* *} \\
(2.24)\end{array}$ & & $\begin{array}{c}0.11^{* * *} \\
(2.65)\end{array}$ & $\begin{array}{c}0.11^{* *} \\
(2.34)\end{array}$ & $\begin{array}{c}0.12 * * * \\
(2.88)\end{array}$ & $\begin{array}{c}0.11^{* * *} \\
(2.71)\end{array}$ & $\begin{array}{c}0.46^{* * *} \\
(2.66)\end{array}$ \\
\hline \multicolumn{9}{|l|}{ LONG-RUN PARAMETERS } \\
\hline In (Government Financed Private R\&D) ${ }_{t-1}$ & $\begin{array}{c}0.36^{* *} \\
(2.02)\end{array}$ & $\begin{array}{l}0.41^{* *} \\
(2.08)\end{array}$ & $\begin{array}{c}0.56^{* *} \\
(2.16)\end{array}$ & $\begin{array}{c}0.45 * * * \\
(2.73)\end{array}$ & $\begin{array}{c}0.34^{* *} \\
(2.17)\end{array}$ & $\begin{array}{l}0.18^{* *} \\
(2.26)\end{array}$ & $\begin{array}{c}0.47^{* * *} \\
(2.72)\end{array}$ & $\begin{array}{c}0.40 * * * \\
(3.03)\end{array}$ \\
\hline $\ln (\text { User Cost })_{t-1}$ & $\begin{array}{l}-0.98^{*} \\
(1.65)\end{array}$ & & & $\begin{array}{c}-1.15^{* *} \\
(2.06)\end{array}$ & $\begin{array}{c}-0.80^{* *} \\
(2.08)\end{array}$ & $\begin{array}{c}-0.49 * * \\
(2.44)\end{array}$ & $\begin{array}{c}-1.00^{* *} \\
(2.04)\end{array}$ & $\begin{array}{l}-1.06 \\
(1.60)\end{array}$ \\
\hline PMR $t_{t-1}$ & & $\begin{array}{l}-0.23 \\
(1.35)\end{array}$ & $\begin{array}{l}-0.26^{*} \\
(1.76)\end{array}$ & & & & $\begin{array}{l}-0.14 \\
(1.04)\end{array}$ & \\
\hline In(Foreign R\&D Stock) $t-1$ & & & & $\begin{array}{l}-1.02 * \\
(1.74)\end{array}$ & & & $\begin{array}{l}-0.98^{*} \\
(1.72)\end{array}$ & \\
\hline In(User Cost $)_{t-1} *($ policy reversals dummy $)$ & & & & & $\begin{array}{c}1.33^{* *} \\
(2.17)\end{array}$ & & & \\
\hline Observations & 512 & 512 & 512 & 512 & 512 & 512 & 512 & 493 \\
\hline Adjusted $\mathrm{R}^{\wedge} 2$ & 0.76 & 0.76 & 0.74 & 0.76 & 0.76 & 0.76 & 0.76 & 0.29 \\
\hline
\end{tabular}

*** $p<0.01,{ }^{* *} p<0.05 * p<0.10$.

Note: $t$-statistics in parentheses. The regressions include country and time fixed effects and standard errors clustered at the country level. The long-run parameters and associated standard errors are calculated according to the technique outlined by Bardsen (1989). Banking reg is a time invariant measure of banking regulation. Policy reversals dummy is a dummy for those countries in the top $10 \%$ of the distribution for reversals in R\&D tax policy (Australia and Belgium). 
tax policy has reversed course is estimated to be positive and statistically significant (Column 5). 19 The sign and magnitude of the coefficient suggests that countries with very high policy volatility gain negligible benefit from a policy-induced reduction in the user cost of $R \& D, 20$

In contrast to Jaumotte and Pain (2005), direct government support is found to be positively related to business-funded R\&D in the long-run. ${ }^{21}$ This implies that government grant and subsidy schemes complement private sector R\&D funding. ${ }^{22}$ While there is some instability in the parameter estimates across the specifications in Table 1, the elasticity in Column 7 implies that a $10 \%$ increase in direct government support for business R\&D is met by an increase in the privately funded R\&D stock by just under $5 \%$ in the long-run. To give some perspective, $10 \%$ is the average annual increase in government support for private $R \& D$ across countries during the first six years of the sample. Unreported regressions suggest that, unlike R\&D tax incentives, direct support measures are not associated with short-run movements in private $R \& D$.

Re-estimating the specification in Column 1 over the 1982-2001 period, the time frame used by Jaumotte and Pain (2005), Table 2 highlights that the direct government support variable is the only one to become statistically insignificant. ${ }^{23}$ The sensitivity of this parameter to the sample period may reflect variation in the design of direct support policies through time. For example, Bloch and Graversen (2008) note that past government support for R\&D was often through contracts where the government would fund as well as purchase the output of firms' R\&D activity. This necessitated a sizeable role for government in selecting the $R \& D$ projects to be undertaken

\footnotetext{
${ }^{19}$ The dummy variable is for countries in the top $10 \%$ of the distribution of tax policy reversals (Australia and Belgium). Interaction terms between the user cost and a dummy variable for countries in the top quartile and top half of the distribution were not statistically significant at conventional levels, though the estimated sign of the coefficients were also positive. The measure of changes in the B-index is dropped in the regressions that include the policy reversals interaction variable given the dummy is defined with regard to movements in the B-index.

${ }^{20} \mathrm{~A}$ hypothesis test finds that the impact of a decline in the user cost on R\&D expenditure in such countries is not statistically different from zero.

${ }^{21}$ David et al. (2000) note that, when input supply is inelastic, studies at the aggregate level may report a positive relationship between publicly financed $R \& D$ and private $R \& D$ that stems from the positive effect of increased government demand on R\&D input prices. To the extent that such input price movements are adequately reflected in the price deflators used to construct the constant price measures, such bias should be avoided. Optimally, a deflator reflecting upstream prices in the R\&D sector would be used to completely allay such concerns, though no reliable such measure is currently available for the full range of countries in the sample.

${ }^{22}$ Unreported regressions using the outlined base specification do not provide support for the idea that the effectiveness of government funding for stimulating $R \& D$ increases up to a particular threshold but decreases thereafter (Guellec and Van Pottelsberghe, 2003).

${ }^{23}$ Running the estimation over two unique sample periods, 1981-1994 and 1996-2008, confirms the sensitivity of the direct government support coefficient to the time period, with the variable only statistically significant in the latter.
} 
and may have meant that much of the R\&D performed was not widely commercially applicable or substituted for privately funded R\&D as a result of rent seeking activity. Recently, however, the allocation of support has become more sensitive to market signals, with matching grants (where a firm commits to match, in a given proportion, the direct support received) an increasingly common feature of government funding programmes (see Blanco Armas et al., 2006; Hall and Maffioli, 2008). Given that a matching scheme stipulates input additionality, it may not be surprising that the more recent time period is important to the empirical finding that government financing encourages additional private $\mathrm{R} \& \mathrm{D} \cdot{ }^{24}$

Another factor behind the observed increasing impact of direct government support may be the recent scaling-back of such schemes across countries (discussed in Section 2.2.2 of this paper). Notwithstanding information asymmetries and the power of some rent-seeking firms, in rationalising direct support governments may first scrap those programmes perceived to be crowding out private $R \& D$ or those deemed to be least effective in encouraging further innovation by businesses. Additionally, the apparent increased potency of direct support may be related to the decline in the share of such spending directed to defence related private $R \& D$ over the recent period.

While a tightening of patent rights should raise the potential returns to R\&D investment for firms (Falk, 2004a; Varsakelis, 2001), the coefficient on the IPR term is not found to be statistically different from zero (Column 2 of Appendix 3).

\subsubsection{Framework Policies}

The empirical results provide only weak evidence that a decrease in product market regulation has a positive effect on the stock of R\&D. While the coefficient on the PMR term is estimated with a negative sign across the specifications in Table 1, the estimate is only weakly significant in 1 of the 3 regressions. With higher PMR limiting new entrants, the estimated (albeit at most weakly significant) sign accords with the theoretical prediction of patent race models that incumbents will invest less in $R \& D$ than entrants as successful innovations may replace incumbent-owned technology that is relatively profitable (Reinganum, 1983). In contrast to the industry based findings of Aghion et al., (2005), unreported regressions find little evidence that a reduction in PMR has more modest benefits for innovation activity in countries where competition is initially high.

There is some limited evidence that the financial regulatory environment influences the speed with which movements in the long-run parameters af-

\footnotetext{
${ }^{24}$ Although the private funds used to match a government grant could come at the expense of another of a firm's R\&D projects. Indeed, the empirical evidence of the importance of matching grants for stimulating $R \& D$ spending is rather mixed (for a review, see Klette and Moen, 2011).
} 
fect R\&D. This is tested, and presented in column 6, by including an interaction variable between the ECM term and a time-invariant indicator of banking regulation that captures regulatory measures relating to bank entry and stability (described in Section 4.3). The positive coefficient estimate suggests that the stock of R\&D may be slower to adjust to changes in the user cost or direct government support in those countries with stricter banking regulation. In such countries financing options may be fewer, slowing the response of firms to a new policy initiative. However, this result should be treated with caution given that the indicator of banking regulation is only observed at one point in time and a time-varying index of financial reform was not found to have a statistically significant effect on business R\&D ${ }^{25}$

In contrast with the finding of Jaumotte and Pain (2005), Columns 4 and 7 highlight the negative and statistically significant coefficient estimate for the foreign R\&D stock. This implies that domestic and foreign R\&D are substitutes, a result in keeping with the evidence of Bloom and Griffith (2001) that domestic $R \& D$ is positively related to the cost of doing such activity abroad. This idea was further investigated with the inclusion of the foreign user cost as a determinant of domestic $R \& D{ }^{26}$ However, the estimated coefficient was not statistically significant despite having the expected positive sign (see Column 3 of Appendix 3).

EPL is not found to have any discernable effect on business R\&D (see Column 4 of Appendix 3). This is unsurprising given the theoretically ambiguous direction of the aggregate-level relationship discussed earlier.

\subsubsection{Dynamic Effects}

The dynamic parameter estimates highlight the importance of macroeconomic factors for the evolution of business $R \& D$ in the short run. The positive coefficient on the GDP growth term suggests procyclicality in R\&D spending, ${ }^{27}$ Higher inflation is estimated to reduce private R\&D, possibly because price instability may create uncertainty over the real value of future

\footnotetext{
${ }^{25}$ The measure of financial reform is an aggregate that summarises financial sector policy along seven dimensions: credit controls and reserve requirements, interest rate controls, entry barriers, state ownership in the banking sector, financial account restrictions, prudential regulations and supervision of the banking sector and securities market policy (for details, see Abiad et al., 2008).

${ }^{26}$ Following Bloom and Griffith (2001), the variable was calculated with weights based on average foreign direct investment flows from the domestic to the foreign country over the sample period.

${ }^{27}$ Previous work (Barlevy, 2007) suggests that while counter-cyclicality might make sense given lower opportunity costs for the resources employed in the R\&D process, R\&D activity is usually found to be pro-cyclical. This may be because firms are more inclined to introduce innovations during boom-times to extract the highest benefit from R\&D that is often only partially excludable and will soon be adopted by other firms. In addition, in the presence of credit constraints, firms' R\&D spending will fluctuate with company earnings (Andrews \& de Serres, 2012).
} 
cash flows and cause firms to defer investment decisions. ${ }^{28}$

The ECM term is significant in all of the specifications in Table 1, giving support for a model that allows short-run adjustments that correct for disequilibrium in the cointegrating relationship with the long-run factors. Consistent with past work (Jaumotte and Pain, 2005) and the idea that it may take time for firms to obtain the necessary capital and labour resources to markedly change $R \& D$ expenditure, the impact of the long-run parameters is estimated to be very protracted. The ECM coefficients in Columns 1-5 imply that just $1.2-1.3 \%$ of the adjustment of $R \& D$ in response to a shock to one of the long-run parameters occurs each year.

The lagged dependent variable is statistically significant in all of the specifications presented in Table 1 . While a least squares model with a lagged dependent variable may create bias in the estimated coefficients when the time dimension of the panel is small (Nickell, 1981), the 28 years of data utilised in this model is large relative to most cross-country panel studies. Indeed, re-estimation with the Arellano-Bond estimator (Arellano and Bond, 1991), designed to correct for such bias, suggests that there is no statistically significant bias present in the Table 1 coefficient estimates.

\subsubsection{Unreported Results}

Unreported results of the analysis include further exploration of the role of innovation policies on R\&D. No evidence was found that public research, either performed by the higher education sector or government labs, encouraged private $R \& D$. This may reflect the broad range of research that is undertaken by such institutions, a large part of which is not immediately commercially applicable. Differential effects from the design of R\&D tax incentives were explored by interacting country dummies for the type of R\&D tax regime (e.g. incremental or volume-based tax credits and whether tax incentives existed for collaboration between business and public institutions) with the user cost variable. However, the estimated effects were not statistically significant. This is likely to partly owe to differences in the design of $R \& D$ tax regimes that cannot be adequately summarised by a time-invariant dummy.

Following some past evidence of a positive relationship between domestic R\&D and foreign direct investment (FDI; Kuemmerle, 1999), a variable reflecting policy barriers to FDI was included ${ }^{29}$ While the estimated coefficient was not statistically significant, such policies may be most relevant for

\footnotetext{
${ }^{28}$ The estimation results are not materially different depending on whether contemporaneous or lagged inflation is included as a dynamic parameter. Theoretically, observable (lagged) inflation is likely to be more important for firm investment decisions and hence estimates for this variable are presented in Table 1.

${ }^{29}$ FDI restrictions are proxied by the OECD FDI Restrictiveness Index that reflects foreign equity restrictions, screening and prior approval requirements, rules for key personnel and other restrictions on the operation of foreign enterprises (for details, see Golub, 2003).
} 
Table 2 - Robustness of the Estimates for the R\&D Equation

\begin{tabular}{|c|c|c|}
\hline & \multicolumn{2}{|c|}{$\begin{array}{c}\text { Dependent Variable }= \\
\Delta \ln (R \& D \text { Stock) }\end{array}$} \\
\hline & (1) & (2) \\
\hline & $1982-2008$ & $1982-2001$ \\
\hline \multicolumn{3}{|l|}{ Short-run dynamics } \\
\hline$\Delta \ln (R \& D \text { Stock })_{t-1}$ & $\begin{array}{l}0.842^{* *} \\
(28.28)\end{array}$ & $\begin{array}{l}0.81 * * * \\
(18.83)\end{array}$ \\
\hline $\mathrm{ECM}_{\mathrm{t}-1}$ & $\begin{array}{c}-0.013 * * * \\
(2.84)\end{array}$ & $\begin{array}{c}-0.022 * * * \\
(4.74)\end{array}$ \\
\hline$\Delta \ln (B \text {-index })_{t}$ & $\begin{array}{c}-0.03 * * \\
(1.96)\end{array}$ & $\begin{array}{c}-0.04 * * \\
(2.10)\end{array}$ \\
\hline Inflation $_{\mathrm{t}-1}$ & $\begin{array}{c}-0.13 * * * \\
(3.47)\end{array}$ & $\begin{array}{c}-0.15^{* * *} \\
(2.80)\end{array}$ \\
\hline GDP growth $t$ & $\begin{array}{l}0.10 * * \\
(2.36)\end{array}$ & $\begin{array}{c}0.15^{* * *} \\
(2.92)\end{array}$ \\
\hline \multicolumn{3}{|l|}{ Long-run parameters } \\
\hline In(Government Financed Private R\&D) t-1 & $\begin{array}{c}0.36 * * \\
(2.02)\end{array}$ & $\begin{array}{l}0,120 \\
(0.88)\end{array}$ \\
\hline $\ln ($ User Cost $) \mathrm{t}-1$ & $\begin{array}{l}-0.98 * \\
(1.65)\end{array}$ & $\begin{array}{c}-1.03^{* *} \\
(1.96)\end{array}$ \\
\hline Constant & $\begin{array}{c}-0.07 * * * \\
(2.84)\end{array}$ & $\begin{array}{c}-0.11^{* * *} \\
(5.48)\end{array}$ \\
\hline Observations & 512 & 379 \\
\hline AdjR2 & 0.76 & 0.75 \\
\hline
\end{tabular}

${ }^{* * *} p<0.01,{ }^{* *} p<0.05{ }^{*} p<0.10$

Note: t-statistics in parentheses. The regression includes country and time fixed effects and standard errors are clustered at the country level.

Table 3 - The Partial Effects of Policy Determinants on Business R\&D

\begin{tabular}{lccccc}
\hline \hline & $\mathbf{( 1 )}$ & $\mathbf{( 2 )}$ & $\mathbf{( 3 )}$ & $\mathbf{( 4 )}$ & $\mathbf{( 5 )}$ \\
\cline { 2 - 6 } & $\begin{array}{c}\text { Sample } \\
\text { mean }\end{array}$ & $\begin{array}{c}\text { Std } \\
\text { deviation }\end{array}$ & $\begin{array}{c}\text { Assumed } \boldsymbol{\Delta} \\
\text { in policy }\end{array}$ & $\begin{array}{c}\text { Long-run } \\
\text { coefficient }\end{array}$ & $\begin{array}{c}\text { Partial Effect } \\
\text { (\%) }\end{array}$ \\
\hline B-Index & 0.94 & 0.05 & -0.05 & -1.00 & 5.8 \\
Govt Financed Private R\&D & 2246 & 657 & $230(10 \% \uparrow)$ & 0.47 & 4.8 \\
PMR & 3.55 & 1.18 & -0.35 & -0.14 & 4.8 \\
\hline \hline
\end{tabular}

Note: The long-run coefficients are taken from column 7 of Table 1. The magnitude of the assumed change in policy is in line with frequently observed annual policy movements across countries through the sample period. The standard deviation is calculated as the average of the country standard deviations. For the B-index, the longrun coefficient is for the user cost term, but the partial effect is calculated based on a rise in the B-index holding all other components of the user cost constant. With reference to the Table 3 columns in bold, partial effects are calculated as $\left[\left(\mathbf{3}^{*} \mathbf{4}\right)^{\star} 100\right]$ for variables that enter the regression in linear form and $\left[((\mathbf{1}+\mathbf{3}) / \mathbf{1})^{\star} \mathbf{1 0 0}-\mathbf{1 0 0}\right]^{\star} \mathbf{4}$ for variables that enter in log form. 
certain types of firms or industries and best investigated using more disaggregated data.

While differences in industry composition are likely to partly explain cross-country variation in R\&D intensity, such differences should be captured by the country fixed effects. Although country dummies will not control for the impact of changes in industry composition through time, several measures of industry composition were included in the R\&D regressions but were not found to be statistically significant 30

\section{Patenting}

The estimation results from the patent model (equation 4) provide evidence of the posited relationship between the stock of $R \& D$ and the flow of new patents, with innovation-specific and framework policies also found to be influential.

\subsubsection{R\&D as a Determinant of New Patents}

The stocks of business and non-business R\&D are estimated to have a positive and statistically significant influence on the number of patents per capita (see Table 4). Evaluated at the sample mean with the estimated coefficients from Column 3 of Table 4, a 1\% increase in business R\&D will increase the number of new patents per capita by just under $1 \%$ in the longrun, while a $1 \%$ increase in non-business $R \& D$ will lead to a $0.4 \%$ rise. The differential effect of business compared with non-business R\&D is consistent with the finding of de Rassenfosse \& van Pottelsberghe (2009) that the number of patents per researcher increases with the share of total R\&D performed by the business sector.

Column 7 presents a specification where the distinction between business and non-business sector R\&D is relaxed, with the estimated coefficient suggesting that a $1 \%$ rise in the total $R \& D$ stock is associated with a $0.6 \%$ increase in patenting in the long-run.

\subsubsection{Innovation Policies}

There is evidence that tax incentives for R\&D have a positive effect on patenting, even after controlling for the impact of R\&D. The estimated longrun elasticity in Column 3 of Table 4 implies that the flow of patents per capita increases by around $2.5 \%$ following an increase in the generosity of R\&D tax incentives equivalent to a 0.05 unit decline in the B-index (for partial effects of the policy variables, see Table 5). Such a reduction corresponds to the average change in the B-index in the sampled countries since 2000. Furthermore, Columns 1, 2, 6 and 7 of Table 4 suggest that the B-index has

\footnotetext{
${ }^{30}$ Past work finds that the rank of countries by R\&D intensity does not change substantially after controlling for differences in industrial structure (OECD, 2006).
} 
a short run effect on patenting activity.

The empirical link between R\&D tax incentives and patenting may reflect that the internal funds available to a firm for developing patents or for undertaking non-R\&D expenditures that contribute to innovation are influenced by the size of $R \& D$ tax incentives received. In addition, some countries allow patent-related expenditures to be eligible under R\&D tax incentive schemes (Warda, 2006). ${ }^{31}$ One of the risks identified with introducing an R\&D tax credit is that firms reclassify unrelated operating expenses as R\&D to reduce their tax bill (see Hall and Van Reenen, 2000). If such activity was pervasive, it is likely that - holding R\&D constant - a decrease in the B-index (i.e. an increase in the generosity of R\&D tax incentives) would be associated with a fall in patenting activity. Instead, these results suggest that an increase in $R \& D$ tax generosity is associated with $R \& D$ that is more productive in terms of patent outcomes.

The results indicate that more protective domestic IPR policy is associated with a higher number of triadic patents. This link is somewhat surprising, as triadic patents are governed by IPR settings in the US, Japan and the EU and not those in the country of the inventor. However, an indirect relationship will exist to the extent that the number of triadic patents filed from a country is positively related to the number of domestic patents and these respond to stronger domestic IPR protection. The coefficient in Column 3 suggests that an increase in patent protection equivalent to Portugal moving IPR policy settings in line with Britain in 2008 (an increase in the index of 0.15 ) is associated with a $3.5 \%$ increase in the number of triadic patents ${ }^{32}$ A natural question is the extent to which an IPR induced increase in patenting indicates more innovation or simply a higher propensity for firms to file patent applications. The fact that the IPR term was not statistically significant in the $R \& D$ regressions does not lend support to the idea that strengthening domestic patent rights will increase innovation intensity (consistent with the findings of Boldrin and Levine, 2008). That said, it is possible that strengthening IPR encourages greater innovation outside of formal R\&D programmes.

As discussed earlier, a key aim of this paper is to investigate any policy complementarities or trade-offs that may exist. With this objective in mind, an interaction term between the IPR indicator and a dummy variable for those countries with above average barriers to firm entry is included in the patent regressions. The estimated coefficient (Column 6) is negative and statistically significant, which suggests that tightening IPR has a weaker impact on patenting in countries with high barriers to entry. Given that raising

\footnotetext{
${ }^{31}$ However, the inclusion of an interaction term between the B-index and a dummy variable for such countries is not found to be statistically significant.

${ }^{32}$ The fact that a component of the IPR index is the 'patentability of software' and a large proportion of patents in some countries are software-related should be kept in mind when interpreting this result.
} 
patent rights entails granting patent holders an (albeit temporary) increase in market power, such a change in policy may reinforce the high barriers to firm entry that exist in some countries. ${ }^{33}$ Young firms are often an important source of new ideas (Akcigit and Kerr, 2010) and the inability of firms to gain access to markets in such countries may be reflected in a lower number of patents. Indeed, the size of the estimate on the interaction term implies that the positive effect on patenting of an increase in IPR is largely offset in those countries with above average barriers to firm entry.

\subsubsection{Framework Policies}

Tighter anticompetitive regulation as represented by an increase in PMR is found to have a direct negative impact on patenting, suggesting a role for pro-competition policies in encouraging innovation (Column 3). A hypothetical reduction in regulation in Finland in 2008 equivalent to the PMR indicator falling to the sample average in that year (a decline of 0.35 ) is estimated to result in a $3 \%$ rise in patents per capita ${ }^{34}$

The importance of international knowledge spillovers is highlighted by the finding that greater exposure to foreign $R \& D$ is associated with higher domestic patenting (Column 4). This contrasts with the evidence from the $R \& D$ regressions and indicates that while greater access to foreign $R \& D$ may cause some firms to scale back domestic R\&D expenditure, knowledge flows from abroad have a positive effect on innovation outputs given a constant stock of domestic R\&D. The estimated coefficient implies that an increase in exposure to trading partner's R\&D stocks from the average level in Spain (around the sample average in 2005) to the higher level in Canada (corresponding to the $75^{\text {th }}$ percentile) would boost patents per capita by around $20 \%$ in the long run. ${ }^{35}$

The results also suggest that policies affecting competition and trade can be complementary in fostering innovation output. Column 5 presents the findings from a specification in which the high barriers to entry dummy is interacted with the foreign $R \& D$ stock variable. The estimated coefficient on the interaction term is negative, indicating that the positive effect on domestic patenting of higher exposure to foreign R\&D is almost completely offset in those countries where high barriers to firm entry exist. As discussed, this

\footnotetext{
${ }^{33}$ For further discussion see OECD (2006).

${ }^{34}$ Unreported regressions could not identify the inverted $U$ relationship between product market competition and innovation intensity highlighted by Aghion et.al (2005). The hypothesis was tested in both the R\&D and patent stock regressions by including an indicator of product market competition as well as its squared term.

${ }^{35}$ Taken together, the estimated coefficients in Table 1 and Table 4 imply that an increase in foreign R\&D will have a negative effect on patenting through the business R\&D channel that will only be partially offset through the direct positive effect of greater access to the foreign knowledge stock on patenting. This must be interpreted with caution, however, as the coefficient on the foreign R\&D stock term in the R\&D regressions does not appear to be very robust (discussed in Section 5.4).
} 
Table 4 - The Determinants of Patents per Capita

\begin{tabular}{|c|c|c|c|c|c|c|c|}
\hline \multirow[t]{2}{*}{ 1986-2008 } & \multicolumn{7}{|c|}{ Dependent Variable $=\Delta \ln ($ Pat per cap) } \\
\hline & (1) & (2) & (3) & (4) & (5) & (6) & (7) \\
\hline \multicolumn{8}{|l|}{ SHORT-RUN DYNAMICS } \\
\hline$\Delta \ln ($ Patents per cap) $t-1$ & $\begin{array}{l}0.025 \\
(0.22)\end{array}$ & & & & & & \\
\hline $\mathrm{ECM}_{\mathrm{t}-1}$ & $\begin{array}{c}-0.49 * * * \\
(3.93)\end{array}$ & $\begin{array}{c}-0.51 * * * \\
(6.75)\end{array}$ & $\begin{array}{c}-0.51 * * * \\
(7.04)\end{array}$ & $\begin{array}{c}-0.46 * * * \\
(6.19)\end{array}$ & $\begin{array}{c}-0.47^{* * *} \\
(6.49)\end{array}$ & $\begin{array}{c}-0.52 * * * \\
(7.15)\end{array}$ & $\begin{array}{c}-0.48 * * * \\
(7.40)\end{array}$ \\
\hline$\Delta \ln (\mathrm{B}-\mathrm{index})_{\mathrm{t}}$ & $\begin{array}{c}-0.62 * * \\
(2.17)\end{array}$ & $\begin{array}{c}-0.55^{* *} \\
(2.24)\end{array}$ & & & & $\begin{array}{c}-0.53^{* *} \\
(2.22)\end{array}$ & $\begin{array}{c}-0.50 * * \\
(2.22)\end{array}$ \\
\hline Inflation $\mathrm{t}-1$ & & & & $\begin{array}{l}-1.52 * \\
(1.92)\end{array}$ & & & \\
\hline \multicolumn{8}{|l|}{ LONG-RUN PARAMETERS } \\
\hline In(Business R\&D/GDP) $t-1$ & $\begin{array}{c}1.40 * * * \\
(3,34)\end{array}$ & $\begin{array}{c}0.99 * * * \\
(3.30)\end{array}$ & $\begin{array}{c}0.93 * * * \\
(3.05)\end{array}$ & $\begin{array}{c}1.30 * * * \\
(3.08)\end{array}$ & $\begin{array}{c}1.54 * * * \\
(3.63)\end{array}$ & $\begin{array}{c}1.14 * * * \\
(3.42)\end{array}$ & \\
\hline In(1+Non-business R\&D/Business R\&D) $t-1$ & $\begin{array}{c}1.21 * * * \\
(2.84)\end{array}$ & $\begin{array}{c}0.90 * * \\
(2.13)\end{array}$ & $\begin{array}{c}0.89 * * \\
(2.13)\end{array}$ & $\begin{array}{c}1.36 * * * \\
(3.71)\end{array}$ & $\begin{array}{c}2.18 * * * \\
(6.70)\end{array}$ & $\begin{array}{c}1.23 * * * \\
(3.06)\end{array}$ & \\
\hline In(Total R\&D) $t-1$ & & & & & & & $\begin{array}{c}0.64 * * * \\
(3.11)\end{array}$ \\
\hline $\ln (B-i n d e x) t-1$ & $\begin{array}{c}-0.95 * * * \\
(3.24)\end{array}$ & $\begin{array}{c}-0.82 * * * \\
(3.31)\end{array}$ & $\begin{array}{c}-0.44^{* *} \\
(2.39)\end{array}$ & & & $\begin{array}{c}-0.69 * * * \\
(2.97)\end{array}$ & $\begin{array}{c}-0.74 * * * \\
(4.44)\end{array}$ \\
\hline $\ln (I P R)_{t-1}$ & & $\begin{array}{c}0.84 * * * \\
(2.68)\end{array}$ & $\begin{array}{c}0.99 * * * \\
(3.01)\end{array}$ & & & $\begin{array}{c}0.72 * * \\
(2.11)\end{array}$ & $\begin{array}{l}0.99 * \\
(1.77)\end{array}$ \\
\hline PMR $t-1$ & & & $\begin{array}{c}-0.09 * * \\
(1.99)\end{array}$ & & & $\begin{array}{l}-0.07^{*} \\
(1.70)\end{array}$ & $\begin{array}{c}-0.10^{* *} \\
(2.54)\end{array}$ \\
\hline In(Foreign R\&D Stock) $t-1$ & & & & $\begin{array}{c}0.33 * * \\
(2.35)\end{array}$ & $\begin{array}{c}0.38 * * * \\
(2.93)\end{array}$ & & \\
\hline In(Foreign R\&D Stock) t-1 $*$ (High barriers dummy) & & & & & $\begin{array}{c}-0.30 * * * \\
(2.68)\end{array}$ & & \\
\hline $\ln (I P R) t$ t 1 (High barriers dummy) & & & & & & $\begin{array}{c}-0.78 * * \\
(2.50)\end{array}$ & \\
\hline Constant & $\begin{array}{c}3.33^{* *} \\
(2.51)\end{array}$ & $\begin{array}{c}2.36 * * * \\
(3.04)\end{array}$ & $\begin{array}{c}2.27 * * * \\
(3.055)\end{array}$ & $\begin{array}{c}1.61 \\
(1.56)\end{array}$ & $\begin{array}{l}2.16^{*} \\
(1.68)\end{array}$ & $\begin{array}{c}2.97 * * * \\
(2.89)\end{array}$ & $\begin{array}{l}-2.34 \\
(1.61)\end{array}$ \\
\hline Observations & 418 & 418 & 418 & 418 & 418 & 418 & 418 \\
\hline AdjR2 & 0.24 & 0.26 & 0.25 & 0.23 & 0.25 & 0.27 & 0.24 \\
\hline
\end{tabular}

*** $p<0.01,{ }^{* *} p<0.05 * p<0.10$.

Note: t-statistics in parentheses. The regressions include country and time fixed effects and standard errors clustered at the country level. The long-run parameters and associated standard errors are calculated according to the technique outlined by Bardsen (1989). High Barriers dummy equals one for those countries with average barriers to entry over the sample period in the top $50 \%$ of the distribution. These countries are Austria, Belgium, Switzerland, Germany, Spain, Finland, France, Italy and Japan.

may reflect incumbent firms with monopoly rights over existing technologies resisting the adoption of new innovations from abroad.

\subsubsection{Dynamic Effects}

The estimated coefficient on the ECM term across the specifications in Table 4 suggests that $50 \%$ of the long-run effect of a change in a policy determinant will occur in the following year, with $50 \%$ of the remaining effect being felt in the year after and so on. This is a much faster response to movements in the long-run parameters than estimated in the R\&D regression, suggesting markedly shorter lags of policy in affecting patenting activity than R\&D. This is not entirely surprising given that once the R\&D stock is determined it is likely to require less planning and resources for a firm to increase or decrease the volume of patent applications than to significantly adjust the volume of R\&D expenditure. 
Table 5 - Partial Effects of Policy Determinants on Patents per Capita

\begin{tabular}{lccccc}
\hline \hline & $\mathbf{( 1 )}$ & $\mathbf{( 2 )}$ & $\mathbf{( 3 )}$ & $\mathbf{( 4 )}$ & $\mathbf{( 5 )}$ \\
\cline { 2 - 6 } & $\begin{array}{c}\text { Sample } \\
\text { mean }\end{array}$ & $\begin{array}{c}\text { Std } \\
\text { deviation }\end{array}$ & $\begin{array}{c}\text { Assumed } \Delta \\
\text { in policy }\end{array}$ & $\begin{array}{c}\text { Long-run } \\
\text { coefficient }\end{array}$ & $\begin{array}{c}\text { Partial Effect } \\
\text { (\%) }\end{array}$ \\
\hline B-Index & 0.94 & 0.05 & -0.05 & -0.44 & 2.5 \\
IPR & 4.10 & 0.50 & 0.15 & 0.99 & 3.5 \\
PMR & 3.55 & 1.18 & -0.35 & -0.09 & 3.1 \\
\hline \hline
\end{tabular}

Note: The long-run coefficients are taken from column 3 of Table 4 . The assumed change in policy is in line with the magnitude of observed annual policy movements through the sample period. The standard deviation is calculated as the average of the country standard deviations. With reference to the Table 5 columns in bold, partial effects are calculated as $\left[\left(3^{*} \mathbf{4}\right) * 100\right]$ for variables that enter the regression in linear form and $\left[((\mathbf{1 + 3}) / \mathbf{1})^{\star} 100-100\right]^{*} \mathbf{4}$ for variables that enter in log form.

There is very weak evidence that inflation has a short-run negative effect on patenting activity above and beyond its impact on R\&D. However, the variable is only statistically significant in the specification in Column 4 . The lagged dependent variable is not found to be statistically significant and is subsequently omitted from all the specifications presented from Columns 2 to 7 .

\section{Multifactor Productivity}

Beneficial knowledge spillovers can derive from innovations that originate either domestically or from abroad. The empirical framework in this paper examines both of these channels, investigating the link between indicators of domestic innovation (the stock of R\&D and patents) and productivity, as well as the role of productivity developments in technological frontier countries that may diffuse to non-frontier countries. The transmission of innovations into higher productivity can be influenced by government policy settings, as illustrated by the empirical results.

\subsubsection{The Impact of $R \& D$ and Patenting on Productivity Growth}

Despite having limitations as a proxy for innovation (Boldrin and Levine, 2013), the number of domestic patents are found to be positively associated with MFP growth (Columns 1 to 3) ${ }^{36}$ This is the case whether a stock or flow measure of patents is used as the regressor, but relies on the presence of Japan in the sample ${ }^{37}$ The results in Table 6 relate to the patent stock (see Appendix 5 for results for patent flows) and reflect not only the direct

\footnotetext{
${ }^{36}$ Including the control variable for business researchers as a share of total industrial employment reduces the chance that the estimated impact of an increase in patents is being overstated by reflecting an increase in the size of the research sector.

${ }^{37}$ The independent variable is the stock of patents in units of 10,000. Unreported regressions (available from the author upon request) indicate that the results in Columns 1-3 of Table 6 are robust to controlling for population size. The population size variable was dropped from the specifications presented here as it was not statistically significant at conventional levels.
} 
productivity effect from patented innovations but also any effect of knowledge spillovers on follow-on innovators that can access relevant technical information once patents are granted. Nonetheless, the results of the specification in Column 2 suggest that the positive effect of higher patenting on MFP is lessened when PMR is relatively high. This may reflect the fact that stricter regulation can impede the efficient allocation of resources (Andrews and Cingano, 2012) and thus make it more difficult for firms to commercialise and maximise the returns from new technologies. Indeed, such a finding accords with recent empirical evidence of the importance of product market competition on innovation in patent intensive industries (Aghion et al., 2013).

The role of absorptive capacity in explaining MFP growth is investigated in Column 3 through the introduction of an interaction term between the number of patents and the share of business enterprise researchers in employment. The coefficient is estimated to be positive and statistically significant, suggesting that an increase in patenting has a larger effect on MFP growth when the proportion of researchers is relatively high. This is consistent with past work (Griffith et al., 2004) and highlights the importance of absorptive capacity for the proliferation of knowledge spillovers once a new idea is made public.

The stock of business R\&D to GDP is estimated to have a positive effect on MFP growth (Column 4) ${ }^{38}$ Given that part of the private labour and capital resources devoted to R\&D are included as production factors in the calculation of MFP, a positive statistical relationship suggests an excess return to business $R \& D$ beyond normal remuneration and the presence of positive externalities (Guellec and van Pottelsberghe, 2004). It must be acknowledged that, especially in the case of multinational enterprises, domestic R\&D may benefit entities outside the domestic economy and that such activity is not explicitly captured in the empirical model. The estimated link between business R\&D and domestic productivity is statistically significant, though the magnitude is in the lower range of estimates from the existing literature (for a review, see Parsons and Phillips, 2007) ${ }^{39}$ There is no evidence of a positive impact of R\&D performed outside the business sector on MFP: the estimated coefficients on terms relating to the stock of govern-

\footnotetext{
${ }^{38}$ Given the empirical link established in Section 5.2.1, R\&D and patenting are not included as regressors at the same time in the MFP regression. Setting aside the issues with multicollinearity, if both variables are included in the same regression (along with frontier growth, MFP gap from the frontier and hours worked), the business R\&D coefficient remains relatively unchanged from that presented in Column 4 of Table 6 while the patents term becomes statistically insignificant at conventional levels.

${ }^{39}$ Of course, past studies are mostly based on less recent data than the present analysis. A series of re-estimations of the coefficient on the business R\&D term over time periods truncated before 2008 indicates that the size of the estimated positive effect of business R\&D on MFP tends to fall as samples include more recent data. Policy conclusions from this exercise are limited, however, as the diminishing size of the R\&D coefficient is not robust to dropping one country at a time from the sample.
} 
ment basic research (Column 6) and higher education R\&D (Column 7) are not statistically significant. It is likely that these types of R\&D affect productivity with long and variable lags since they are not directly performed by the business sector, although experimenting with longer lag structures did not uncover a stronger statistical relationship 40 This is consistent with much of the existing empirical literature that finds the productivity return to many forms of publicly financed R\&D to be near zero (Sveikauskas, 2007). While the estimation also found no direct impact of the foreign R\&D stock on MFP growth (Column 5), much of this effect may be captured in the terms relating to the MFP gap and MFP growth of the frontier country.

\section{The Effect of Knowledge Flows from Technological Leader Coun- tries}

Highlighting the importance of the diffusion of innovations from abroad, MFP growth in the frontier country is found to have a positive and significant effect on MFP in less productive countries. ${ }^{41}$ Additionally, the estimated coefficient on the MFP gap term indicates that technological adoption is more beneficial for countries that are further behind the productivity frontier. While of similar magnitude to estimates in past work (Griffith et al., 2004; Nicoletti and Scarpetta, 2003) the coefficient on the gap term is not statistically significant in 4 of the 17 specifications, which may reflect a degree of multicollinearity with some of the other regressors.

The estimation results also provide evidence that international knowledge spillovers can be influenced by government policy. The estimate for the interaction term in Column 9 indicates that the speed of convergence to the frontier will be slower for countries that have higher levels of product market regulation. This is consistent with the empirical evidence in Section 5.2.3 of this paper and past research (Conway et al., 2006) that suggests that incumbents with high market power may resist the adoption of new innovations from abroad.

\footnotetext{
${ }^{40}$ When all of the R\&D variables are included in the same specification (Column 8 ), the business R\&D term becomes statistically insignificant at conventional levels. This is partly due to an increase in the standard error that the pairwise correlation coefficients indicate may arise from multicollinearity with the other measures of domestic R\&D.

${ }^{41}$ The frontier country is controlled for, so that the coefficient on the frontier growth variable is the estimated effect for non-frontier countries.
} 


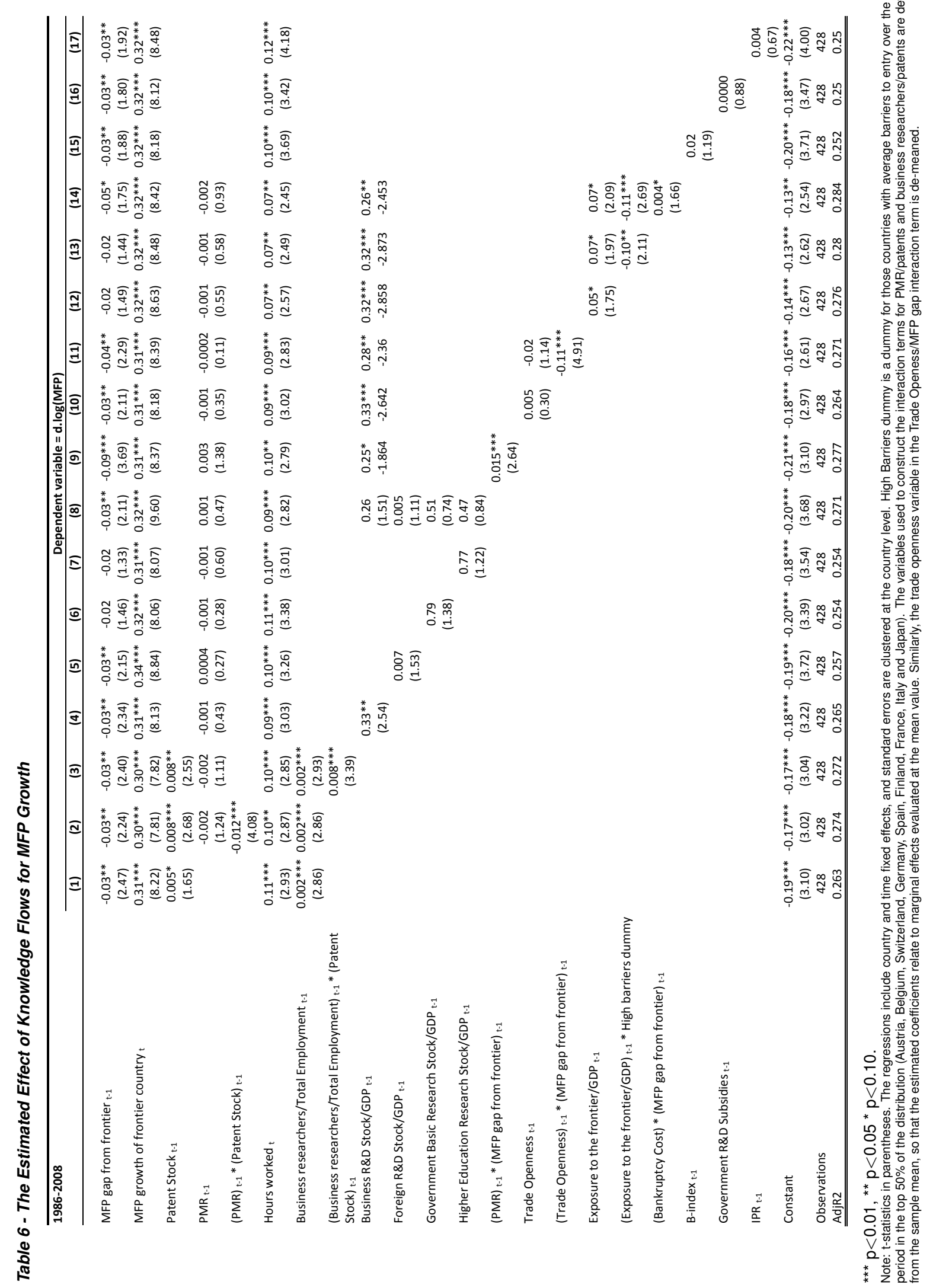


The results also suggest that productivity convergence will be faster for countries that are more open to trade (Column 11). Greater trade openness may assist the diffusion of foreign knowledge through the ideas embodied in imported goods and is often positively related to other factors that can benefit productivity growth such as foreign direct investment (Seim, 2009) and international labour mobility (Ortega and Peri, 2012) 42

A number of past studies have explored the importance of geographical proximity to technological leaders in explaining knowledge spillovers and the innovation intensity of non-frontier entities (e.g. Audretsch and Feldman, 2003). Here, this spatial dimension is represented by a variable reflecting geographical distance from a country's capital city to the capital city of the frontier country. A country is a very broad geographic unit for which to investigate spatial knowledge spillovers, with existing studies more inclined to focus on cities or even postal codes. Nevertheless, the results in Column 12 indicate that countries with higher geographic exposure to the technological leader exhibit higher productivity. This effect is dependent on framework policies though, with the benefits of spatial knowledge flows completely offset in economies with high barriers to firm entry that restrict the ability of young firms to build on the ideas generated in neighbouring countries (Column 13).

There is also weak support for the idea that government policies which increase the cost of firm exit may cause resources to be trapped in inefficient firms that would otherwise be released to businesses that are relatively adept at technological adoption (Bartelsman et al., 2008) ${ }^{43}$ This is illustrated by the positive coefficient on the 'bankruptcy cost' interaction term in Column 14 which suggests that technological adoption from abroad is slower in countries with more punishing bankruptcy regimes.

\subsubsection{Innovation Policies and MFP Growth}

Columns 15, 16 and 17 of Table 6 present the results when policy instruments that appear to be influential in encouraging private R\&D and patenting activity are included in the MFP regression. Increases in $R \& D$ tax incentives, direct government support and patent rights do not appear to have a direct positive effect on MFP growth, despite the regressions not controlling for the stock of patents or domestic business R\&D ${ }^{44}$ This is somewhat surprising given that these policy variables were found to affect the mea-

\footnotetext{
${ }^{42}$ This supports the conclusions of Giles and Stroomer (2006). In the presence of concerns about the potential endogeneity of the trade openness variable (Frankel and Romer, 1999), an avenue for further work may be to confirm the result using instrumental variable (IV) estimation (insofar as an appropriate time-varying instrument can be found).

${ }^{43}$ This is consistent with the empirical findings of Andrews and Cingano (2012) that low exit costs make it less likely that resources are tied up in inefficient firms.

${ }^{44}$ The finding that stricter patent rights are not associated with higher MFP growth contrasts with the results of Bouis et al., (2011) at the country level, though is consistent with the review of the literature outlined by Boldrin and Levine (2013).
} 
sures of innovative activity that are significant determinants of productivity growth (in Sections 5.1 and 5.2). Possible explanations for the lack of a statistical relationship between innovation policies and MFP may be that:

- The indirect nature of the relationship means that the estimation is more likely to be affected by measurement error.

- The types of R\&D or patents that these policies encourage are not positively related to productivity. Fiscal incentives induce the marginal project that will have a relatively low value to businesses and perhaps also to society. This would be surprising in the case of direct support measures that are thought to be targeted at R\&D activities with high social worth, but may highlight the information asymmetries that are often seen as a reason against such government intervention. In relation to IPR, the lack of a significant finding may suggest that tightening patent rights causes an increase in firm's propensity to patent without significantly increasing innovation intensity.

- Although the activity induced by innovation policies may benefit productivity, such policies may also have unintended detrimental effects for MFP. As discussed, tightening patent rights involves affording some market power to innovators which can have negative implications for competition. Similarly, recent work suggests that $R \& D$ tax incentives can protect incumbents to the detriment of potential entrants, slowing down the reallocation process (Bravo-Biosca et al., 2012).

- Fiscal incentives for R\&D entail an opportunity cost in the form of the welfare-enhancing projects that could otherwise be funded by the government or the private sector activities suppressed by any additional taxation levied on firms to pay for incentives. If the foregone projects are as beneficial to productivity as the innovation encouraged by fiscal incentives, there should be no identifiable effect of these $R \& D$ policies on aggregate productivity growth.

To gain a better understanding of whether innovation-specific policies have an overall benefit to society, a full net welfare analysis of the policy measures is required. While outside the scope of this paper, previous studies at the individual country level make clear that innovation policies are not necessarily welfare-enhancing (Parsons and Phillips, 2007). Whether such measures accrue a net social benefit is likely to depend to a large extent on the magnitude of the spillovers from induced innovation activity along with institutional and policy settings in a given country.

\section{Conclusion}

This paper explores the policy determinants of business R\&D and patenting activity and establishes an empirical link between such measures of innovation and productivity growth at the country level. The effect of various policies on the diffusion of knowledge has also been examined and where 
possible, any consequences stemming from the interaction of government policies highlighted. The results suggest that innovation specific policies such as R\&D tax incentives, direct government support of business R\&D and patent rights achieve their objective of encouraging private sector innovative activity (insofar as such activity is adequately proxied by business $R \& D$ and patent count measures). However, no evidence of a direct effect of such policies on aggregate productivity growth could be found. Given that the economic impact of innovation policies may be heterogeneous across countries, any future attempt to collect cross-country data on the design of these measures would be informative.

A recurring theme through the findings is the importance of well-designed framework policies relating to competition in incentivising innovation and the returns to new ideas. While there is evidence that lower PMR may have a positive effect on private innovation activity, the results also suggest that pro-competition policies are important for the effective diffusion of knowledge from both domestic and overseas sources.

Although using highly aggregated data is preferable for assessing the spillovers to innovation, the estimated effects presented in this paper are averages across countries, sectors and firms. As such, the findings will benefit from any further work using industry or firm level data that can explore the channels through which these aggregate effects become apparent. 


\section{References}

Abiad, A., Detragiache, E. Tressel, T., 2008. A New Database of Financial Reforms. IMF Working Paper WP/08/266. IMF, Washington D.C.

Acharya, V.V., Baghai, R.P., Subramanian, K.V., 2010. Labour Laws and Innovation. NBER Working Paper, no. 16484.

Akcigit, U., Kerr, W.R., 2010. Growth through Heterogeneous Innovations. Penn Institute for Economic Research Working Paper, 10-035.

Aghion, P., Howitt, P., 1992. A Model of Growth Through Creative Destruction, NBER Working Paper, No. 3223.

Aghion, P., Howitt, P., 1997. Endogenous Growth Theory. The MIT Press.

Aghion, P., Bloom, N., Blundell, R., Griffith, R., Howitt, P., 2005. Competition and Innovation: An InvertedU Relationship. Quarterly Journal of Economics 120, 2, 701-728. doi:/10.1162/0033553053970214

Aghion, P., Howitt,P., Prantl, S., 2013. Patent rights, product market reforms, and innovation. NBER Working Paper, No. 18854.

Andrews, D., Criscuolo, C., 2013. Knowledge-based capital, innovation and resource allocation, OECD Economics Department Working Paper, No. 1046. OECD, Paris.

Andrews, D., Cingano, F., 2012. Regulation, Allocative Efficiency and Productivity: Evidence from Firms in OECD Countries. OECD Economics Department Working Paper, No. 996. OECD, Paris.

Andrews, D., de Serres, A., 2012. Intangible Assets, Resource Allocation and Growth. OECD Economics Department Working Paper, No. 989. OECD, Paris.

Ang, J.B., 2011. Financial Development, Liberalization and Technological Deepening? European Economic Review 55, 688-701. doi:/10.1016/j.euroecorev.2010.09.004

Arellano, M., Bond, S., 1991. Some Tests of Specification for Panel Data: Monte Carlo Evidence and an Application to Employment Equations. Review of Economic Studies 58, 277-297. doi:/10.2307/2297968

Arrow, K.J. 1962. Economic Welfare and the Allocation of Resources to Invention. The Rate and Direction of Inventive Activity. Princeton University Press. 
Audretsch, D.B., Feldman, M.P., 2003. Knowledge Spillovers and the Geography of Innovation. The Handbook of Urban and Regional Economics 4, 2713-2739. doi:/10.1016/S1574-0080(04)80018-X

Autor, D.H., 2003. Outsourcing at Will: the Contribution of Unjust Dismissal Doctrine to the Growth of Employment Outsourcing. Journal of Labor Economics 211, 1-42.

Bardsen, G., 1989. Estimation of Long Run Coefficients in Error Correction Models. Oxford Bulletin on Economics and Statistics 51, 345-350. doi:/10.1111/j.1468-0084.1989.mp51003008.x

Barlevy, G., 2007. On the Cyclicality of Research and Development. American Economic Review 97, 1131-1164. doi:/10.1257/aer.97.4.1131

Bartelsman, E.J., Gautier, P.A., De Wind, J., 2010. Employment Protection, Technology Choice, and Worker Allocation. IZA Discussion Paper No. 4895.

Bartelsman, E.J., Perotti, E., Scarpetta, S., 2008. Barriers to Exit, Experimentation and Comparative Advantage. RICAFE2 Working Paper No. 056. London School of Economics.

Bassanini, A., Nunziata, L., Venn, D., 2009. Job Protection Legislation and Productivity Growth in OECD Countries. Economic Policy 24, 349-402. doi:/10.1111/j.1468-0327.2009.00221.x

Blanco Armas, E., Goldberg, I., Jaffe, A., Muller, T., Sunderland, Trajtenberg, M., 2006. Public Financial Support for Commercial Innovation: Europe and Central Asia Knowledge Economy Study Part 1. World Bank Chief Economist's Regional Working Paper Series 1.

Bloch, C., Graversen, E.K., 2008. Additionality of Public R\&D Funding in Business R\&D. The Danish Centre for Studies in Research and Research Policy. Working Paper 2008/5.

Bloom, N., Griffith, R., 2001. The Internationalisation of UK R\&D. Fiscal Studies 33, 337-355. doi:/10.1111/j.1475-5890.2001.tb00045.x

Bloom, N., Griffith, R., van Reenen, J., 2002. Do R\&D Tax Credits Work? Evidence from a Panel of Countries 1979-1997. Journal of Public Economics 85, 1-31. doi:/10.1016/S0047-2727(01)00086-X

Boldrin, M., Levine, D.K., 2008. Against Intellectual Monopoly. Cambridge Books, Cambridge University Press.

Boldrin, M., Levine, D.K., 2013. The Case Against Patents. Journal of Economic Perspectives 27, 3-22. doi:/10.1257/jep.27.1.3 
Bouis, R., Duval, R., Murtin, F., 2011. The Policy and Institutional Drivers of Economic Growth Across OECD and Non-OECD Economies: New Evidence from Growth Regressions. OECD Economics Department Working Papers, No. 843. OECD Publishing.

Caselli, F., 2005. Accounting for CrossCountry Income Differences. Handbook of Economic Growth. Edition 1, Vol. 1, Chapter 9, 679-741.

Coe, D.T., Helpman, E., 1995. International R\&D Spillovers. European Economic Review 39, 859-887. doi:/10.1016/0014-2921(94)00100-E

Conway, P., de Rosa, D., Nicoletti, G., Steiner, F., 2006. Regulation, Competition and Productivity Convergence. OECD Economics Department Working Papers, No. 509. OECD Publishing.

Czarnitzki, D., Kraft, K., Thorwarth, S., 2008. The Knowledge Production of ' $\mathrm{R}$ ' and ' $\mathrm{D}$ '. The Centre for European Economic Research, Discussion Paper No. 08-046.

Danguy, J., de Rassenfosse, G., Van Pottelsberghe de la Potterie, B., 2009. The R\&D-Patent Relationship: An Industry Perspective. European Investment Bank Papers 14, 170-195.

David, P.A., Hall, B.H., Toole, A.A., 2000. Is Public R\&D a Complement or Substitute for Private R\&D? A Review of the Econometric Evidence. Research Policy 29, 497-529. doi:/10.1016/S0048-7333(99)00087-6

De Boef, S., Granato, J., 2000. Testing for Cointegrating Relationships with Near-integrated Data. Political Analysis 8, 99-117.

de Rassenfosse, G., van Pottelsberghe, B., 2009. A Policy Insight into the R\&D-Patent Relationship. Research Policy 38, 779-792. doi:/10.1016/j.respol.2008.12.013

de Serres, A., Kobayakawa, S., Slok, T., Vartia, L., 2006. Regulation of Financial Systems and Economic Growth in OECD Countries: An Empirical Analysis. OECD Economic Studies 43, 77-113.

Falk, M., 2004a. What Drives Business R\&D Intensity Across OECD Countries? WIFO Working Papers, 236.

Falk, M., 2004b. What Determines Patents per Capita in OECD Countries. WIFO Working Papers, 242.

Frankel, J.A., D., Romer, 1999. Does Trade Cause Growth? American Economic Review 89, 379-99. doi:/10.1257/aer.89.3.379

Giles, D.E.A., Stroomer, C.N., 2006. Does Trade Openness Affect the Speed of Output Convergence? Some Empirical Evidence. Empirical Economics 31, 883-903. doi:/10.1007/s00181-006-0060-y 
Golub, S., 2003. Measures of Restrictions On Inward Foreign Direct Investment for OECD Countries. OECD Economic Studies 3, 85-116. doi:/10.1787/eco_studies-v2003-art3-en

Goolsbee, A., 1998. Does Government R\&D Policy Mainly Benefit Scientists and Engineers? National Bureau of Economic Research Working Paper 6532.

Griffith, R., Redding S., Van Reenan, J., 2004. Mapping the Two Faces of R\&D: Productivity Growth in a Panel of OECD Industries. The Review of Economics and Statistics 86, 883-895. doi:/10.1162/0034653043125194

Griffith, R., Macartney, G., 2010. Employment Protection Legislation, Multinational Firms and Innovation. CEPR Discussion Papers, No. 7628.

Guellec, D., Van Pottelsberghe de la Potterie, B., 2003. The Impact of Public R\&D Expenditure on Business R\&D. Economics of Innovation and New Technology 12, 225-243. doi:/10.1080/10438590290004555

Guellec, D., Van Pottelsberghe de la Potterie, B., 2004. From R\&D to Productivity Growth: Do the Institutional Settings and the Source of Funds of R\&D Matter? Oxford Bulletin of Economics and Statistics 66, 353-378. doi:/10.1111/j.1468-0084.2004.00083.x

Hall, R., Jorgenson, D., 1967. Tax Policy and Investment Behaviour. American Economic Review, 1034-1076.

Hall, B.H., Mairesse, J., 1995. Exploring the Relationship Between R\&D and Productivity in French Manufacturing Firms. Journal of Econometrics 65, 263-293. doi:/10.1016/0304-4076(94)01604-X

Hall, B.H., Van Reenen, J., 2000. How Effective Are Fiscal Incentives for R\&D? A Review of the Evidence. Research Policy 29, 449-469. doi:/10.1016/S0048-7333(99)00085-2

Hall, B.H., Maffioli, A., 2008. Evaluating the Impact of Technology Development Funds in Emerging Economies: Evidence from Latin America, NBER Working Paper, no. 13835.

Hall, B.H., Mairesse, J., Mohnen, P., 2009. Measuring the Returns to R\&D. Handbook of the Economics of Innovation, 1034-1076.

Hausman, J., Hall, B., Griliches, Z., 1984. Econometric Models for Count Data with an Application to the Patents-R\&D Relationship. Econometrica 52, 909-938. doi:/10.2307/1911191

Hu, A.G.Z., Png, I.P.L., 2013. Patent Rights and Economic Growth: Evidence from CrossCountry Panels of Manufacturing Industries. Oxford Economic Papers 65, 675-698. doi:/10.1093/oep/gpt011 
Jaffe, A.B., Sanyal, P., 2005. Peanut Butter Patents versus the New Economy: Does the Increased Rate of Patenting Signal More Invention or Just Lower Standards? Annals of Economics and Statistics 79/80, 211-240.

Jaumotte, F., Pain, N., 2005. From Ideas to Development: The Determinants of R\&D and Patenting. OECD Economics Department Working Paper No. 457. OECD, Paris.

Johansson, Å., Guillemette, Y., Murtin, F., Turner, D., Nicoletti, G., de la Maisonneuve, C., Bagnoli, P., Bousquet, G., Spinelli, F., 2012. Long-Term Growth Scenarios. OECD Economics Department Working Paper No. 1000. OECD, Paris.

Klette, T.J., Møen, J., 2011. R\&D Investment Responses to R\&D Subsidies: A Theoretical Analysis and Microeconometric Study. Discussion Paper No.15, Department of Finance and Management Science, Norwegian School of Economics.

Kuemmerle, W., 1999. The Drivers of Foreign Direct Investment into Research and Development: An Empirical Investigation. Journal of International Business Studies 30, 1-24. doi:/10.1057/palgrave.jibs.8490058

Lichtenberg, F.R., van Pottelsberghe de la Potterie, B., 1998. International R\&D spillovers: A comment. European Economic Review 42, 1483-1491. doi:/10.1016/S0014-2921(97)00089-5

Li, W.C.Y, 2012. Depreciation of Business R\&D Capital. Paper Prepared for the XXXII General Conference of The International Association for Research in Income and Wealth,

Lokshin, B., Mohnen, P., 2009. What Does it Take for an R\&D Tax Incentive Policy to be Effective? Updated UNU-MERIT Working Paper No. 29, University of Maastricht.

Maskus, K.E., Neumann, R., Seidel, T., 2012. How National and International Financial Development Affect Industrial R\&D. European Economic Review 56, 72-83. doi:/10.1016/j.euroecorev.2011.06.002

Montmartin, B., 2013. BusinessFunded R\&D Intensity: Impact and Complementarity of Public Financial Support. Universitat de Barcelona Working Paper, WP4/06.

Nadiri, I., 1993. Innovations and Technological Spillovers. NBER Working Paper No. 4423. Cambridge, Ma.

Nickell, S., 1981. Biases in Dynamic Models with Fixed Effects, Econometrica 49, 1417-1426. doi:/10.2307/1911408 
Nicoletti, G., Scarpetta S., Boylaud, O., 2000. Summary Indicators of Product Market Regulation with an Extension to Employment Protection Legislation. OECD Economics Department Working Paper No. 226. OECD, Paris.

Nicoletti, G., Scarpetta S., 2003. Regulation, Productivity, and Growth: OECD Evidence. Policy Research Working Paper, No. 2944.

OECD 2006. Encouraging Innovation: An Overview of Performance and Policies. Economic Policy Reforms: Going For Growth, Chapter 3, 55-80.

Ortega, F., Peri, G., 2012. The Effect of Trade and Migration on Income. NBER Working Paper, No. 18193. Cambridge, Ma.

Park, W.G., 2008. International Patent Protection: 1960-2005. Research Policy 37, 761-766. doi:/10.1016/j.respol.2008.01.006

Parente, S.L., Prescott, E.C., 2000. Barriers to Riches. MIT Press: Cambridge, MA.

Parsons, M., Phillips, N., 2007. An Evaluation of the Federal Tax Credit for Scientific Research and Experimental Development. Department of Finance Canada Working Paper, 2007-08.

Pesaran, M.H., Shin, Y., 1999. An Autoregressive Distributed Lag Modelling Approach to Cointegration Analysis. In S. Strom (Ed.), Econometrics and Economic Theory in the 20th Century. Cambridge University, Chapter 11.

Pesaran, M.H., Shin, Y., Smith, R.P., 1997. Estimating Long-Run Relationships in Dynamic Heterogeneous Panels. DAE Working Papers Amalgamated Series 9721.

Pesaran, M.H., Smith, R.P., 1995. Estimating Long-Run Relationships from Dynamic Heterogeneous Panels. Journal of Econometrics 68, 79-113. doi:/10.1016/0304-4076(94)01644-F

Pindyck, R.S., 1992. Investment of Uncertain Cost. NBER Working Paper No. 4175. Cambridge, Ma.

Primo, D.M., Jacobsmeier, M.L., Milyo, J., 2007. Estimating the Impact of State Policies and Institutions with Mixed-Level Data. State Politics and Policy Quarterly Vol. 7, No. 4 (Winter 2007. 446-459. doi:/10.1177/153244000700700405

Reinganum, J.F., 1983. Uncertain Innovation and the Persistence of Monopoly. The American Economic Review 73, 741-748.

Saint-Paul, G. 1997. Is Labour Rigidity Harming Europe's Competitiveness? The Effect of Job Protection on the Pattern of Trade and Welfare. European Economic Review 41, 499-506. doi:/10.1016/S0014-2921(97)00017-2 
Saint-Paul, G. 2002. Employment Protection, International Specialization, and Innovation. European Economic Review 46, 375-395. doi:/10.1016/S0014-2921(01)00093-9 


\section{Data Annex}

\section{R\&D Stocks}

R\&D stocks are calculated using the perpetual inventory method followed by Jaumotte and Pain (2005). Specifically, the starting value is calculated according to the formula $S_{i, t=0}=R_{i, t+1} /\left(g_{i}+\delta\right)$ where $g$ is the sample mean growth rate of $R \& D$ expenditures over the estimation period and $\delta$ is the constant depreciation rate of R\&D capital. In subsequent time periods, the R\&D stock evolves according to the accumulation equation $S_{i, t+1}=R_{i, t+1}+(1-\delta) S_{t}$.

For the R\&D regressions, the business sector stock is calculated with a starting value at 1980 . This is not the case for Portugal which, due to missing data, has a starting value at 1981 . For the patent regressions, the nonbusiness sector R\&D stock is taken as the difference between the wholeeconomy and business sector stocks. As whole-economy R\&D expenditure data for Belgium are only available from 1983, the R\&D stocks for all countries used in these regressions are calculated with a starting value at 1982 (this approach is taken here as the sample for the patent regressions does not start until 1986). The non-business sector stock will include higher education expenditure on $R \& D$, government intramural expenditure on $R \& D$ and direct government support for private R\&D.

\section{Multifactor Productivity}

MFP is calculated in the manner outlined by Johansson et al. (2012). Specifically, the supply side of the economy is modelled according to a Cobb-Douglas production function with constant returns to scale:

$$
Y_{i t}=K_{i t}^{\alpha}\left(A_{i t} h c_{i t} L_{i t}\right)^{1-\alpha}
$$

where $Y, K, A, h c$ and $L$ denote output, physical capital, technical progress (MFP), human capital per worker, total employment and subscript $t$ and $i$ denote year and country. The share of capital is set equal to 1/3. After some manipulations, MFP is derived as:

$$
A_{i t}=Y_{i t} /\left(\frac{K_{i t}}{Y_{i t}}\right)^{\alpha /(1-\alpha)} h c_{i t} L_{i t} .
$$

GDP is expressed in constant 2005 PPP USD terms, capital stocks are taken from the OECD Productivity Database or calculated from investment series (excluding residential housing investment) based on the perpetual inventory method assuming a $4 \%$ annual depreciation rate. Human capital stocks are derived from data relating to the average number of years of schooling across the population aged 25-64 and an assumption for the returns to education (see Johansson et al., 2012 for further details). 


\section{Descriptive Statistics}

\begin{tabular}{|c|c|c|c|c|c|}
\hline \multicolumn{6}{|l|}{ R\&D Regression (1982-2008) } \\
\hline Variable & Obs & Mean & Std. Dev. & Min & Max \\
\hline R\&D Stock & 512 & 94,999 & 199,225 & 475 & $1,302,874$ \\
\hline R\&D Flow & 512 & 17,611 & 36,949 & 107 & 234,252 \\
\hline B-index & 512 & 0.94 & 0.11 & 0.56 & 1.05 \\
\hline Inflation & 512 & 0.04 & 0.03 & -0.01 & 0.27 \\
\hline GDP growth & 512 & 0.03 & 0.02 & -0.06 & 0.11 \\
\hline User Cost & 512 & 0.18 & 0.03 & 0.08 & 0.26 \\
\hline Government Financed Private R\&D & 512 & 2,250 & 6,644 & 2 & 44,375 \\
\hline PMR & 512 & 3.5 & 1.4 & 0.9 & 6.0 \\
\hline Foreign R\&D & 512 & 8,840 & 10,524 & 225 & 71,473 \\
\hline \multicolumn{6}{|l|}{ Patent Regression (1986-2008) } \\
\hline Variable & Obs & Mean & Std. Dev. & Min & Max \\
\hline Patents per capita & 418 & 59 & 47 & 0 & 188 \\
\hline B-index & 418 & 0.94 & 0.11 & 0.56 & 1.05 \\
\hline Inflation & 418 & 0.03 & 0.02 & -0.01 & 0.130 \\
\hline Business R\&D/GDP & 418 & 0.06 & 0.03 & 0.00 & 0.15 \\
\hline (1+Non-business R\&D/Business R\&D) & 418 & 1.94 & 0.59 & 1.34 & 4.782 \\
\hline Total R\&D & 418 & 176,809 & 352,537 & 2,029 & $2,066,418$ \\
\hline IPR & 418 & 4.22 & 0.55 & 1.67 & 4.880 \\
\hline PMR & 418 & 3.23 & 1.24 & 0.94 & 5.83 \\
\hline Foreign R\&D Stock & 418 & 10,263 & 11,110 & 534 & 71,473 \\
\hline \multicolumn{6}{|l|}{ MFP Regression (1986-2008) } \\
\hline Variable & Obs & Mean & Std. Dev. & Min & Max \\
\hline MFP gap from frontier & 428 & -0.31 & 0.19 & -0.78 & 0.000 \\
\hline MFP growth of frontier country & 428 & 0.007 & 0.025 & -0.081 & 0.058 \\
\hline Patent stock & 428 & 0.63 & 1.17 & 0.000 & 4.99 \\
\hline PMR & 428 & 3.28 & 1.27 & 0.94 & 5.83 \\
\hline Hours worked & 428 & 1.69 & 0.15 & 1.35 & 2.10 \\
\hline Business researchers/Total Emp. & 428 & 4.60 & 2.84 & 0.23 & 14.35 \\
\hline Business R\&D stock/GDP & 428 & 0.062 & 0.034 & 0.004 & 0.149 \\
\hline Foreign R\&D stock/GDP & 428 & 1.44 & 1.01 & 0.12 & 7.54 \\
\hline Government Basic Research stock/GDP & 428 & 0.014 & 0.007 & 0.002 & 0.034 \\
\hline Higher Education Research stock/GDP & 428 & 0.023 & 0.009 & 0.004 & 0.049 \\
\hline Trade Openness & 428 & 0.69 & 0.35 & 0.16 & 1.83 \\
\hline Exposure to the frontier/GDP & 428 & 0.047 & 0.064 & 0.000 & 0.371 \\
\hline Bankruptcy Cost & 428 & 7.41 & 4.81 & 1.00 & 22.00 \\
\hline B-index & 428 & 0.94 & 0.11 & 0.56 & 1.05 \\
\hline Government R\&D subsidies & 428 & 2,213 & 6,456 & 3 & 44,375 \\
\hline IPR & 428 & 4.20 & 0.578 & 1.670 & 4.880 \\
\hline
\end{tabular}




\section{Geographical Exposure to the Frontier}

The variable in the MFP regressions representing geographical exposure to the MFP leader for a country $i$ is calculated by weighting the frontier level of MFP by the distance between the capital city of country $i$ and the capital city of the frontier country in kilometres. Distances are obtained from the web-page of Jon Haveman at Macalester College ${ }^{45}$ In the regressions, the variable enters as weighted units of frontier MFP per unit of domestic GDP.

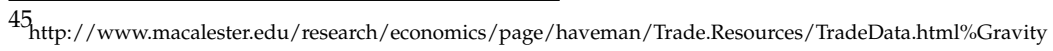




\section{Appendix 1 - Calculating the User Cost of R\&D}

The user cost of $R \& D$ can be written as:

$$
U C_{i t}=\left[\frac{1-A_{i t}^{d}-A_{i t}^{c}}{1-v_{i t}}\right]\left(r_{i t}+\delta_{i t}\right)\left(\frac{P R D_{i t}}{P_{i t}}\right)
$$

where $A^{d}$ and $A^{c}$ denote the present value of depreciation allowances and tax credits and $v$ the corporate tax rate. The first term in the user cost equation represents the B-index (described in Warda 2001), the final term is the price deflator for $R \& D$ relative to the price deflator for the goods and services produced. Consistent with the approach taken by Jaumotte and Pain (2005), the price deflator term is assumed equal to unity in the empirical work. 


\section{Appendix 2 - Calculating Standard Errors for the Long Run Parameters}

The long-run parameters from the ECM model are calculated by employing the transformation detailed by Bardsen (1989). This gives the procedure for a general ECM model such as:

$$
\Delta Y_{t}=\alpha_{0}+\alpha_{1}^{*} Y_{t-1}+\beta_{1}^{*} \Delta X_{t}+\beta_{2}^{*} X_{t-1}+\epsilon_{t}
$$

where the long-run multiplier for variable $X_{t}$ is calculated as $\hat{\theta}_{X}=-\hat{\beta}_{2}^{*} / \hat{\alpha}_{1}^{*}$. A disadvantage of following this procedure is that the standard error from the long-run multiplier is not directly estimated. Instead, the variancecovariance matrix for the estimated equation must be obtained and the variance of $\theta_{X}$ calculated as:

$$
\operatorname{va\hat {a}}\left(\hat{\theta}_{X}\right)=\left(\hat{\alpha}_{1}^{*}\right)^{-2}\left[\operatorname{var}\left(\hat{\beta}_{2}^{*}\right)+\left(\hat{\theta}_{X}\right)^{2} \operatorname{vâ} r\left(\hat{\alpha}_{1}^{*}\right)+2 \hat{\theta}_{X} \operatorname{cov} v\left(\hat{\beta}_{2}^{*}, \hat{\alpha}_{1}^{*}\right)\right]
$$




\section{Appendix 3 - Unreported Results from the R\&D Regression}

\begin{tabular}{|c|c|c|c|c|}
\hline & \multicolumn{4}{|c|}{ Dependent Variable $=\Delta \ln (R \& D$ Stock $)$} \\
\hline & $\begin{array}{l}\text { (1) } \\
\text { Base }\end{array}$ & (2) & (3) & (4) \\
\hline \multicolumn{5}{|l|}{ Short-run dynamics } \\
\hline$\Delta \ln (R \& D \text { Stock })_{t-1}$ & $\begin{array}{c}0.842^{* * *} \\
(28.28)\end{array}$ & $\begin{array}{c}0.843^{* * *} \\
(28.41)\end{array}$ & $\begin{array}{c}0.843 * * * \\
(28.80)\end{array}$ & $\begin{array}{c}0.842^{* * *} \\
(27.99)\end{array}$ \\
\hline$E C M t-1$ & $\begin{array}{c}-0.013^{* * *} \\
(2.84)\end{array}$ & $\begin{array}{c}-0.012^{* * *} \\
(2.77)\end{array}$ & $\begin{array}{c}-0.011^{* * * *} \\
(2.93)\end{array}$ & $\begin{array}{c}-0.013^{* * *} \\
(2.80)\end{array}$ \\
\hline$\Delta \ln (B \text {-index })_{t}$ & $\begin{array}{c}-0.035^{* *} \\
(1.96)\end{array}$ & $\begin{array}{c}-0.036^{* *} \\
(2.00)\end{array}$ & $\begin{array}{c}-0.035^{*} \\
(1.94)\end{array}$ & $\begin{array}{c}-0.035^{*} \\
(1.95)\end{array}$ \\
\hline Inflation $\mathrm{t}-1$ & $\begin{array}{c}-0.133^{* * * *} \\
(3.47)\end{array}$ & $\begin{array}{c}-0.143^{* * *} \\
(2.78)\end{array}$ & $\begin{array}{c}-0.139 * * * \\
(3.28)\end{array}$ & $\begin{array}{c}-0.129 * * * \\
(3.33)\end{array}$ \\
\hline GDP growth $\mathrm{t}$ & $\begin{array}{c}0.105^{* *} \\
(2.36)\end{array}$ & $\begin{array}{c}0.104^{* *} \\
(2.34)\end{array}$ & $\begin{array}{c}0.103^{* *} \\
(2.33)\end{array}$ & $\begin{array}{c}0.105^{* *} \\
(2.38)\end{array}$ \\
\hline \multicolumn{5}{|l|}{ Long-run parameters } \\
\hline In (Government Financed Private R\&D) $t-1$ & $\begin{array}{c}0.359 * * \\
(2.02)\end{array}$ & $\begin{array}{c}0.412^{* *} \\
(2.07)\end{array}$ & $\begin{array}{c}0.356^{* *} \\
(2.09)\end{array}$ & $\begin{array}{c}0.367^{* *} \\
(2.00)\end{array}$ \\
\hline $\ln (\text { User Cost })_{t-1}$ & $\begin{array}{l}-0.98^{*} \\
(1.65)\end{array}$ & $\begin{array}{l}-1.210 \\
(1.63)\end{array}$ & $\begin{array}{c}-1.007^{*} \\
(1.65)\end{array}$ & $\begin{array}{l}-0.969 \\
(1.56)\end{array}$ \\
\hline $\ln (I P R))_{t-1}$ & & $\begin{array}{l}-0.479 \\
(0.42)\end{array}$ & & \\
\hline $\ln ($ Foreign User Cost) $\mathrm{t}-1$ & & & $\begin{array}{c}0,83 \\
(0.76)\end{array}$ & \\
\hline $\mathrm{EPL}_{\mathrm{t}-1}$ & & & & $\begin{array}{l}-0.094 \\
(0.65)\end{array}$ \\
\hline Constant & $\begin{array}{c}-0.070 * * * \\
(2.84)\end{array}$ & $\begin{array}{c}-0.061^{* *} \\
(2.06)\end{array}$ & $\begin{array}{c}-0.052^{*} \\
(1.76)\end{array}$ & $\begin{array}{c}-0.065^{* *} \\
(2.46)\end{array}$ \\
\hline Observations & 512 & 512 & 512 & 512 \\
\hline AdjR2 & 0.759 & 0.759 & 0.759 & 0.759 \\
\hline
\end{tabular}

${ }^{* * *} p<0.01,{ }^{* *} p<0.05{ }^{*} p<0.10$

Note: $t$-statistics in parentheses. The regressions include country and time fixed effects, standard errors are clustered at the country level. 


\section{Appendix 4 - The Determinants of Growth in the Patent Stock}

\begin{tabular}{|c|c|c|c|c|c|c|c|}
\hline \multirow{2}{*}{ 1986-2008 } & \multicolumn{7}{|c|}{ Dependent Variable $=\Delta \ln ($ Pat Stock per cap) } \\
\hline & (1) & (2) & (3) & (4) & (5) & (6) & (7) \\
\hline \multicolumn{8}{|l|}{ SHORT-RUN DYNAMICS } \\
\hline$\Delta \ln (\text { Patent Stock per cap) })_{t-1}$ & $\begin{array}{c}0.296 * * * \\
(5.58)\end{array}$ & $\begin{array}{c}0.285^{* * *} \\
(6.08)\end{array}$ & $\begin{array}{c}0.286^{* * *} \\
(6.18)\end{array}$ & $\begin{array}{c}0.296 * * * \\
(5.32)\end{array}$ & $\begin{array}{c}0.294 * * * \\
(5.90)\end{array}$ & $\begin{array}{c}0.278^{* * *} \\
(6.75)\end{array}$ & $\begin{array}{c}0.281^{* * *} \\
(5.78)\end{array}$ \\
\hline$E C M M_{t-1}$ & $\begin{array}{c}-0.16^{* * *} \\
(4.11)\end{array}$ & $\begin{array}{c}-0.16^{* * *} \\
(3.84)\end{array}$ & $\begin{array}{c}-0.16^{* * *} \\
(4.26)\end{array}$ & $\begin{array}{c}-0.14 * * * \\
(4.21)\end{array}$ & $\begin{array}{c}-0.15^{* * *} \\
(4.48)\end{array}$ & $\begin{array}{c}-0.17^{* * *} \\
(3.87)\end{array}$ & $\begin{array}{c}-0.14^{* * *} \\
(4.92)\end{array}$ \\
\hline$\Delta \ln (B-i n d e x)_{t}$ & $\begin{array}{c}-0.20^{* *} \\
(2.26)\end{array}$ & $\begin{array}{c}-0.19 * * \\
(2.20)\end{array}$ & & & & $\begin{array}{c}-0.18^{* *} \\
(2.16)\end{array}$ & $\begin{array}{c}-0.16^{* *} \\
(2.24)\end{array}$ \\
\hline Inflation $\mathrm{t}-1$ & & & & $\begin{array}{l}-0.46 \\
(1.61)\end{array}$ & & & \\
\hline \multicolumn{8}{|l|}{ LONG-RUN PARAMETERS } \\
\hline In(Business R\&D/GDP) $t-1$ & $\begin{array}{c}1.28 * * * \\
(3,22)\end{array}$ & $\begin{array}{c}0.97 * * * \\
(2.83)\end{array}$ & $\begin{array}{c}0.90^{* * *} \\
(2.62)\end{array}$ & $\begin{array}{c}1.18^{* * *} \\
(2.93)\end{array}$ & $\begin{array}{c}1.41 * * * \\
(3.53)\end{array}$ & $\begin{array}{c}1.10^{* * *} \\
(3.14)\end{array}$ & \\
\hline In(1+Non-business R\&D/Business R\&D) $t-1$ & $\begin{array}{c}0.90^{* * *} \\
(2.68)\end{array}$ & $\begin{array}{l}0.67^{*} \\
(1.76)\end{array}$ & $\begin{array}{l}0.66^{*} \\
(1.74)\end{array}$ & $\begin{array}{c}1.03 * * * \\
(3.00)\end{array}$ & $\begin{array}{c}1.80 * * * \\
(6.88)\end{array}$ & $\begin{array}{l}0.95 * * \\
(2.43)\end{array}$ & \\
\hline $\ln ($ Total R\&D) $t-1$ & & & & & & & $\begin{array}{l}0.62^{* *} \\
(1.98)\end{array}$ \\
\hline $\ln (B-i n d e x) t-1$ & $\begin{array}{c}-0.96^{* * *} \\
(3.24)\end{array}$ & $\begin{array}{c}-0.85^{* * *} \\
(3.38)\end{array}$ & $\begin{array}{c}-0.44 * * \\
(2.25)\end{array}$ & & & $\begin{array}{c}-0.71 * * * \\
(2.96)\end{array}$ & $\begin{array}{c}-0.68^{* * *} \\
(3.41)\end{array}$ \\
\hline $\ln (I P R)_{t-1}$ & & $\begin{array}{c}0.63^{* * *} \\
(2.46)\end{array}$ & $\begin{array}{c}0.79 * * * \\
(3.07)\end{array}$ & & & $\begin{array}{c}0,54 \\
(1.62)\end{array}$ & $\begin{array}{c}0.90 * * * \\
(3.37)\end{array}$ \\
\hline $\mathrm{PMR}_{\mathrm{t}-1}$ & & & $\begin{array}{c}-0.10^{* *} \\
(2.33)\end{array}$ & & & $\begin{array}{c}-0.09 * * \\
(1.99)\end{array}$ & $\begin{array}{c}-0.12^{* *} \\
(2.59)\end{array}$ \\
\hline In(Foreign R\&D Stock) $\mathrm{t}-1$ & & & & $\begin{array}{l}0.33^{*} \\
(1.94)\end{array}$ & $\begin{array}{c}0.37^{* *} \\
(2.43)\end{array}$ & & \\
\hline In(Foreign R\&D Stock) $\mathrm{t}-1^{*}$ (High barriers dummy) & & & & & $\begin{array}{c}-0.28^{* * *} \\
(2.69)\end{array}$ & & \\
\hline $\ln (\mathrm{IPR})_{\mathrm{t}-1} *($ High barriers dummy) & & & & & & $\begin{array}{c}-0.70^{* *} \\
(1.97)\end{array}$ & \\
\hline Constant & $\begin{array}{c}1.23 * * * \\
(2.79)\end{array}$ & $\begin{array}{l}1.01^{* *} \\
(2.41)\end{array}$ & $\begin{array}{l}0.98^{* *} \\
(2.56)\end{array}$ & $\begin{array}{c}0,65 \\
(1.47)\end{array}$ & $\begin{array}{c}0,83 \\
(1.63)\end{array}$ & $\begin{array}{c}1.19 * * * \\
(2.44)\end{array}$ & $\begin{array}{l}-0,45 \\
(0.82)\end{array}$ \\
\hline Observations & 418 & 418 & 418 & 418 & 418 & 418 & 418 \\
\hline $\operatorname{AdjR} 2$ & 0.19 & 0.20 & 0.20 & 0.18 & 0.19 & 0.21 & 0.19 \\
\hline
\end{tabular}

${ }^{* * *} p<0.01,{ }^{* *} p<0.05{ }^{*} p<0.10$.

Note: $\mathrm{t}$-statistics in parentheses. The regressions include country and time fixed effects, standard errors are clustered at the country level and calculated according to the technique outlined by Bardsen (1989) for the long run parameters. High Barriers dummy is a dummy for those countries with average barriers to entry over the sample period in the top $50 \%$ of the distribution. These countries are Austria, Belgium, Switzerland, Germany, Spain, Finland, France, Italy and Japan. 


\section{Appendix 5 - MFP and the Flow of New Patents}

\begin{tabular}{|c|c|c|c|}
\hline \multirow[t]{2}{*}{ 1986-2008 } & \multicolumn{3}{|c|}{ Dependent variable $=d \cdot \log (\mathrm{MFP})$} \\
\hline & (1) & (2) & (3) \\
\hline MFP gap from frontier $t-1$ & $\begin{array}{c}-0.03^{* *} \\
(2.40)\end{array}$ & $\begin{array}{c}-0.03^{* *} \\
(2.01)\end{array}$ & $\begin{array}{c}-0.03^{* *} \\
(2.14)\end{array}$ \\
\hline MFP growth of frontier country $t$ & $\begin{array}{c}0.31^{* * *} \\
(8.22)\end{array}$ & $\begin{array}{c}0.30^{* * *} \\
(7.76)\end{array}$ & $\begin{array}{c}0.30 * * * \\
(7.68)\end{array}$ \\
\hline Patent flow ${ }_{t-1}$ & $\begin{array}{c}0.0018^{*} \\
(1.86)\end{array}$ & $\begin{array}{c}0.0031^{* * *} \\
(2.72)\end{array}$ & $\begin{array}{c}0.0031^{* *} \\
(2.34)\end{array}$ \\
\hline PMR $\mathrm{t}-1_{1}$ & & $\begin{array}{l}-0.003 \\
(1.32)\end{array}$ & $\begin{array}{l}-0.002 \\
(1.19)\end{array}$ \\
\hline$(P M R)_{t-1} *(\text { Patent flow })_{t-1}$ & & $\begin{array}{c}-0.0036^{* * *} \\
(4.17)\end{array}$ & \\
\hline Hours worked $t$ & $\begin{array}{c}0.11^{* * *} \\
(2.93)\end{array}$ & $\begin{array}{c}0.10^{* * *} \\
(2.93)\end{array}$ & $\begin{array}{c}0.10 * * * \\
(2.95)\end{array}$ \\
\hline Business researchers/Total employment $t_{t-1}$ & $\begin{array}{c}0.002^{* * *} \\
(2.84)\end{array}$ & $\begin{array}{c}0.002^{* * *} \\
(2.80)\end{array}$ & $\begin{array}{c}0.002 * * * \\
(2.88)\end{array}$ \\
\hline (Business researchers/Total employment) ${ }_{\mathrm{t}-1} *(\text { Patent flow) })_{\mathrm{t}-1}$ & & & $\begin{array}{c}0.002 * * * \\
(2.71)\end{array}$ \\
\hline Constant & $\begin{array}{c}-0.19^{* * *} \\
(3.11)\end{array}$ & $\begin{array}{c}-0.17^{* * *} \\
(3.05)\end{array}$ & $\begin{array}{c}-0.18^{* * *} \\
(3.10)\end{array}$ \\
\hline Observations & 428 & 428 & 428 \\
\hline AdjR2 & 0.27 & 0.27 & 0.27 \\
\hline
\end{tabular}

${ }^{* * *} p<0.01,{ }^{* *} p<0.05 * p<0.10$

Note: $\mathrm{t}$-statistics in parentheses. The regressions include country and time fixed effects, standard errors are clustered at the country level. 